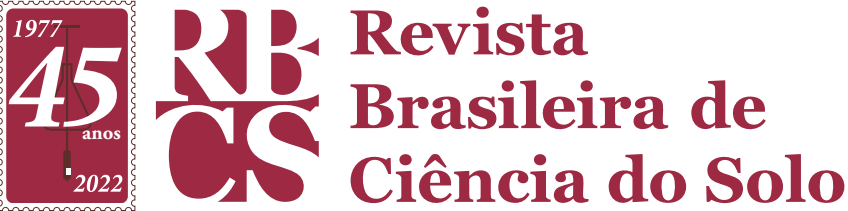

Division - Soil Use and Management | Commission - Soil Fertility and Plant Nutrition

\title{
Nitrogen use efficiency and grain yield of corn hybrids as affected by nitrogen rates and sowing dates in subtropical environment
}

\author{
Antonio Eduardo Coelho ${ }^{(1) *}(D)$, Luis Sangoi ${ }^{(1)}(1)$, Alvadi Antonio Balbinot Junior ${ }^{(2)}\left(D^{D}\right.$, \\ Hugo François Kuneski ${ }^{(1)}$ iD and Marcos Cardoso Martins Júnior ${ }^{(1)}$ (iD \\ (1) Universidade do Estado de Santa Catarina, Departamento de Agronomia, Programa de Pós-Graduação em \\ Produção Vegetal, Lages, Santa Catarina, Brasil. \\ (2) Empresa Brasileira de Pesquisa Agropecuária, Embrapa Soja, Londrina, Santa Catarina, Brasil.
}

* Corresponding author:

E-mail: coelhoagro7@gmail.com

Received: July 27, 2021

Approved: October 18, 2021

How to cite: Coelho $A E$, Sangoi L, Balbinot Junior AA, Kuneski HF, Martins Júnior MC. Nitrogen use efficiency and grain yield of corn hybrids as affected by nitrogen rates and sowing dates in subtropical environment. Rev Bras Cienc Solo. 2022;46:e0210087.

https://doi.org/10.36783/18069657rbcs20210087

Editors: José Miguel Reichert (DD and Jeferson Dieckow (D).

Copyright: This is an open-access article distributed under the terms of the Creative Commons Attribution License, which permits unrestricted use, distribution, and reproduction in any medium, provided that the original author and source are credited.
ABSTRACT: Delay of sowing date in subtropical environments with long growing seasons can modify the yield response of corn hybrids to nitrogen $(\mathrm{N})$ fertilization. This study evaluated the effects of the sowing time, and $\mathrm{N}$ top-dress rate on corn hybrids' yield and $\mathrm{N}$-use efficiency with different cycles. Two field experiments were carried out in subtropical environment of southern Brazil. The following factors were investigated: corn hybrids (AG9025, super early cycle and P30F53, early cycle), sowing times (early and late spring), and $\mathrm{N}$ top-dress rates $\left(0,150,300\right.$ and $\left.450 \mathrm{~kg} \mathrm{ha}^{-1}\right)$. The delay of sowing date from early to late spring reduced $10 \%$ the number of kernels per ear, decreasing grain yield. Corn presented lower yield potential in late sowings (-24\%), associated with a smaller response of grain yield to the $\mathrm{N}$ rate increase. The maximum corn yield was achieved at a rate of $360 \mathrm{~kg} \mathrm{ha}^{-1}$ of $\mathrm{N}$ in early spring sowing and $300 \mathrm{~kg} \mathrm{ha}^{-1}$ in late spring. The hybrid with early cycle presented greater yield stability and higher $\mathrm{N}$ use efficiency than the super early cycle hybrid in the late sowing. The $\mathrm{N}$ agronomic efficiency use is $47 \%$ lower in late spring sowing than in early spring sowing. Regardless of the sowing date, the $\mathrm{N}$ use efficiency decreased 0.08 for each $\mathrm{kg} \mathrm{ha}^{-1} \mathrm{~N}$ rate increase. This study suggests a reduction of at least $20 \%$ in the $\mathrm{N}$ top-dress rate when the sowing date of corn is delayed to late spring in southern Brazil to decrease $\mathrm{N}$ losses and production costs.

Keywords: Zea mays L., nitrogen fertilization, sowing time, yield stability, relative maturity group. 


\section{INTRODUCTION}

In southern Brazil, there has been an intense replacement of the first corn crop by soybean due to the adequate availability of technologies, market prices and liquidity of the oleaginous (Cattelan and Dall'Agnol, 2018). The first corn crop area in Brazil decreased from 9.8 million ha in 1999/2000 to 4.2 million ha in the 2019/2020 growing season (Conab, 2020). One of the factors that limits the economic viability of first corn crop in southern Brazil is its low yield. In the 2018/2019 growing season, the Brazilian average productivity of first corn crop was only $8.2 \mathrm{Mg} \mathrm{ha}^{-1}$ (Conab, 2020). However, experiments carried out by Kolling et al. (2019) and Panison et al. (2019) showed that first corn crop has a yield potential higher than $15 \mathrm{Mg} \mathrm{ha}^{-1}$ in this region. The generation of information that allows better understanding of management practices for high corn grain yield is fundamental to enhance the cereal-cultivated first crop area, enabling rotation with soybean in spring/summer and increasing the sustainability and resilience of grain production systems in southern Brazil.

Currently, the achievement of high yields associated with a high $\mathrm{N}$ use efficiency is fundamental to the production of cereal crops (Duan et al., 2019). A yield-based approach is often used to make $\mathrm{N}$ fertilizer recommendations for corn (Stevens et al., 2005). However, efficient use of $\mathrm{N}$ fertilizers is becoming increasingly important in modern corn production due to environmental and economic costs associated with $\mathrm{N}$ fertilization (Cantarella et al., 2018). In this context, variables such as $\mathrm{N}$ agronomic efficiency (NAE) (Baligar et al., 1990), N recovery efficiency (NRE) (Vargas et al., 2015), amount of $\mathrm{N}$ exported by grains ( $N$ exported) (Rocha et al., 2020) and partial $N$ balance (PN balance) (Austin et al., 2019) can be useful for more rational decision-making in the management of $\mathrm{N}$ fertilization. The NAE is expressed as the grain production per mass of $\mathrm{N}$ applied. The NRE, demonstrates how much of the applied $\mathrm{N}$ was allocated to the grains. Nitrogen exported shows how much of the applied $\mathrm{N}$ is removed and exported of the field with the harvest and commercialization of grain production. The PN Balance estimates the input or output of $\mathrm{N}$ in the production system.

Different crop management practices, as well as hybrid genetic characteristics, can affect $\mathrm{N}$ use efficiency (Haegele and Below, 2013; DeBruin et al., 2017). The choice of the sowing date is one of the most important management decisions. It defines the atmospheric conditions that the crop is subjected to during its development cycle, influencing plant growth and grain yield (Sindelar et al., 2010; Bonelli et al., 2016; Jiang et al., 2020). A strong interaction between the hybrid cycle and sowing date affects the corn grain yield (Tsimba et al., 2013; Baum et al., 2019; Jiang et al., 2020). When corn is sown at the end of spring, the higher soil and air temperatures accelerate the crop development from the plant emergence to flowering (Lizaso et al., 2018). This effect is more pronounced in super early hybrids because they require fewer thermal units to reach the tasseling stage (Coelho et al., 2020). The faster development may decrease the plant ability to take up nitrogen and use the nutrient for ear development and kernel filling. The earlier hybrids may demand higher $\mathrm{N}$ rates, especially when sowing is performed in early spring when the yield potential is greater (Sangoi et al., 2016). Therefore, this interaction between sowing date and corn hybrid may also influence the crop response to $\mathrm{N}$ fertilization (Jiang et al., 2020).

When there is adequate water availability, the ideal corn sowing time in southern Brazil is during early spring because it allows the flowering and grain filling stages to match the period of greatest solar radiation and adequate air temperature (Sangoi et al., 2010; Lizaso et al., 2018). In addition, early spring sowings decrease the severity of foliar and stalk diseases (Coelho et al., 2019; Berghetti et al., 2020). The better environmental conditions faced by corn when it is sown in early spring provide conditions for the crop to reach a higher yield ceiling. It is possible that the greater yield potential at this sowing time increases the crop demand for $\mathrm{N}$ and its response to $\mathrm{N}$ rates, in comparison to the 
late spring sowings. However, the technical recommendations for $\mathrm{N}$ fertilization of corn in the subtropical environments of Brazil do not consider the sowing date as a factor to define the recommended $N$ rate (CQFS RS/SC, 2016; NEPAR-SBCS, 2017). This lapse can limit yield, increase production costs and reduce $\mathrm{N}$ use efficiency. In many situations, farmers grow crops with greater income potential, such as garlic, tobacco and onions, during the winter/spring seasons, delaying the corn sowing date to the end of spring. This fact is not considered to define the appropriate $\mathrm{N}$ rate for corn.

Elucidation of the interactions between the sowing date and hybrid cycle is necessary to develop the most accurate recommendations regarding the $\mathrm{N}$ rate. This study evaluated the effects of the sowing time and $\mathrm{N}$ top-dress rates on the yield and $\mathrm{N}$ use efficiency of corn hybrids with different cycles in a subtropical environment of southern Brazil.

\section{MATERIALS AND METHODS}

\section{Characterization of the experiment}

The experiment was conducted during the growing seasons of 2015/2016 and 2016/2017. In the first year, the trial was carried out in Lages, Santa Catarina, Brazil ( $27^{\circ} 50^{\prime} 35^{\prime \prime} \mathrm{S}$, $50^{\circ} 29^{\prime} 45^{\prime \prime} \mathrm{W}$ and $849 \mathrm{~m}$ a.s.l.). The regional climate is Cfb (Alvares et al., 2013), mesothermal with mild summers and average temperatures during the hottest month below $22^{\circ} \mathrm{C}$ and a well-distributed rainfall. The soil in the experimental area is classified as Nitossolo Vermelho Distrófico Típico (Santos et al., 2013), which corresponds to Oxisol (Kandic) (Soil Survey Staff, 2014). Table 1 presents the soil physical and chemical properties in the 0.00-0.20 m layer. The experimental area has been cropped under a no-tillage system for fifteen years.

In the second year, the experiment was conducted in Atalanta, Santa Catarina, Brazil $\left(27^{\circ} 26^{\prime} 03^{\prime \prime} \mathrm{S}, 49^{\circ} 42^{\prime} 06^{\prime \prime} \mathrm{W}\right.$ and $586 \mathrm{~m}$ a.s.l.). The regional climate is Cfa (Alvares et al., 2013), subtropical mesothermal humid from hot summers, with an average annual temperature between 18 and $19{ }^{\circ} \mathrm{C}$, an average annual precipitation between 1300 and $1500 \mathrm{~mm}$ and a relative air humidity of 82 to $85 \%$. The soil in the experimental area is classified as Cambissolo Háplico distrófico típico (Santos et al., 2013), which corresponds to Inceptisol (Soil Survey Staff, 2014). Table 1 presents the soil physical and chemical properties in the $0.00-0.20 \mathrm{~m}$ layer. The experimental area was cropped under a no-tillage system for twelve years.

Table 1. Soil texture and chemical properties in the $0.00-0.20 \mathrm{~m}$ layer of both locations, before the implementation of the experiments

\begin{tabular}{|c|c|c|}
\hline Soil property & Lages & Atalanta \\
\hline Clay $\left(\mathrm{g} \mathrm{kg}^{-1}\right)$ & 530 & 452 \\
\hline Silt $\left(\mathrm{g} \mathrm{kg}^{-1}\right)$ & 243 & 408 \\
\hline Sand $\left(\mathrm{g} \mathrm{kg}^{-1}\right)$ & 227 & 140 \\
\hline Organic matter $\left(\mathrm{g} \mathrm{kg}^{-1}\right)$ & 36 & 23 \\
\hline $\mathrm{pH}\left(\mathrm{H}_{2} \mathrm{O}\right)$ & 5.1 & 5.7 \\
\hline $\mathrm{H}+\mathrm{Al}(\mathrm{SMP})\left(\mathrm{cmol}_{\mathrm{c}} \mathrm{dm}^{-3}\right)$ & 5.2 & 6.2 \\
\hline$P\left(m g d m^{-3}\right)$ & 13 & 80 \\
\hline $\mathrm{K}\left(\mathrm{mg} \mathrm{dm} \mathrm{m}^{-3}\right)$ & 195 & 223 \\
\hline $\mathrm{Ca}^{2+}\left(\mathrm{cmol}_{\mathrm{c}} \mathrm{dm}^{-3}\right)$ & 7.0 & 7.6 \\
\hline $\mathrm{Mg}^{2+}\left(\mathrm{cmol}_{\mathrm{c}} \mathrm{dm}^{-3}\right)$ & 2.5 & 2.1 \\
\hline $\mathrm{Al}^{3+}\left(\mathrm{cmol}_{\mathrm{c}} \mathrm{dm}^{-3}\right)$ & 0.3 & 0.0 \\
\hline Cation exchange capacity $\left(\mathrm{cmol}_{\mathrm{C}} \mathrm{dm}^{-3}\right)$ & 20.8 & 13.8 \\
\hline
\end{tabular}

${ }^{*} \mathrm{pH}$ in $\mathrm{H}_{2} \mathrm{O}$ was determined in 1:2.5 soil:water ratio; $\mathrm{P}$ and $\mathrm{K}$ were extracted with Mehlich-1. $\mathrm{Ca}^{2+}, \mathrm{Mg}^{2+}$, and $\mathrm{Al}^{3+}$ were extracted with $\mathrm{KCl} 1 \mathrm{~mol} \mathrm{~L}^{-1}$. 
Figure 1 presents the sequential water balance according to the methodology described by Thornthwaite and Mather (1955), considering plant available water capacities of 70 and $60 \mathrm{~mm}$ for Lages and Atalanta, respectively. The water deficiency (DEF) was determined considering how much the soil-plant system decreased the potential evapotranspiration. Water excess (EXC) corresponds to water that could not be retained and was drained in-depth (gravitational water). Plant available water (PAW) corresponds to the water balance stored in the soil. The experimental plots received supplementary irrigation using a fixed sprinkler irrigation system whenever necessary, maintaining the soil moisture at $80 \%$ of its gravimetric content, close to the field capacity.

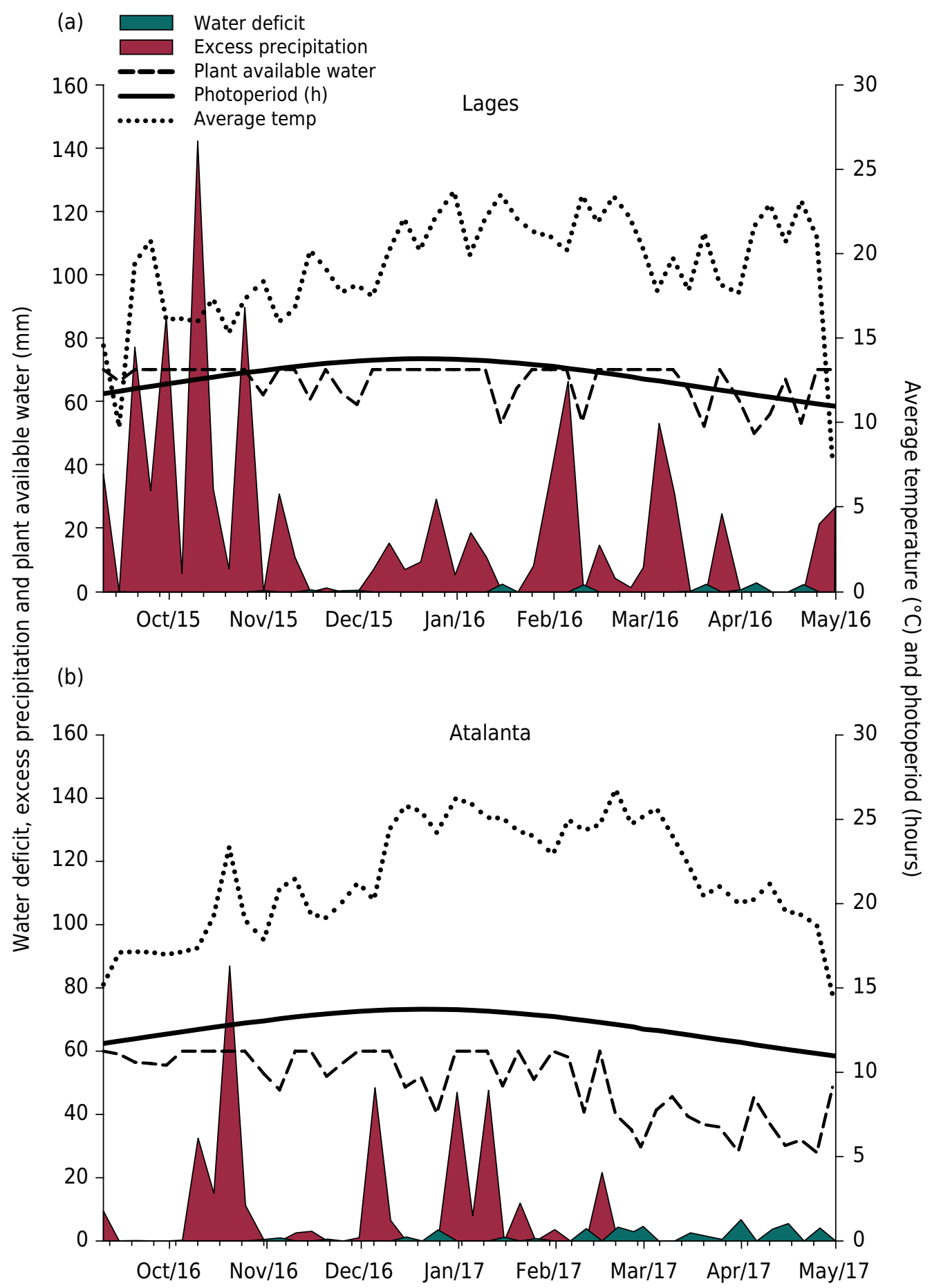

Figure 1. Sequential water balance "by the 5-day period" according to the methodology described by Thornthwaite and Mather (1955). DEF: water deficiency; EXC: water excess; PlantPAW: plant available water; Temp Med: average temperature; and Photoperiod. 


\section{Crop management}

The plant density was 75.000 plants $\mathrm{ha}^{-1}$, and the row spacing was $0.70 \mathrm{~m}$. Manual seeders were used, dropping three seeds. Thinning was carried out when the plants reached the growth stage of V2, two fully expanded leaves, according to the scale of Ritchie et al. (1993). At each sowing date, $30 \mathrm{~kg} \mathrm{ha}^{-1} \mathrm{~N}, 300 \mathrm{~kg} \mathrm{ha}^{-1} \mathrm{P}_{2} \mathrm{O}_{5}$ and $200 \mathrm{~kg} \mathrm{ha}^{-1} \mathrm{~K}_{2} \mathrm{O}$ were applied to the soil surface to produce $21 \mathrm{Mg} \mathrm{ha}^{-1}$ (CQFS RS/SC, 2004). Top-dress $\mathrm{N}$ rates were equally divided into three application periods at the growth stages of V4, V8 and V12, according to the scale of Ritchie et al. (1993). The source of nitrogen fertilizer used was urea.

\section{Sampling and measurements}

The number of ears per plant (ear index), and the percentage of plants without ears (barren plants) were determined on the harvest day. Harvests were carried out manually, in an area of $8.4 \mathrm{~m}^{2}$, at the center of each plot. The grain yield was determined at a standard moisture of $13 \%$, after drying the kernels at $65^{\circ} \mathrm{C}$ until they reach a constant weight. The weight of 1,000 kernels was determined in a sample of 400 kernels, oven-dried at $65{ }^{\circ} \mathrm{C}$ and converted to a moisture of $13 \%$. The number of kernels per ear was estimated by dividing the kernel mass and the number of ears harvested in each plot.

The $\mathrm{N}$ content in grains (NCG) was determined after sulfuric digestion by the Kjeldhal method. The amount of $\mathrm{N}$ exported by grains ( $\mathrm{N}$ Exported) was calculated using the equation:

N Exported $\left(\mathrm{kg} \mathrm{ha}^{-1}\right)=\mathrm{NCG}\left(\mathrm{kg} \mathrm{kg}\right.$ grain $\left.^{-1}\right) \times$ YG $\left(\mathrm{kg}\right.$ grain ha $\left.{ }^{-1}\right)$

in which NCG is the N content in grains and YG is the grain yield.

Nitrogen use efficiency was evaluated by the following parameters: $N$ agronomic efficiency (NAE); $\mathrm{N}$ recovery efficiency (NRE); and partial $\mathrm{N}$ balance (PN balance).

Nitrogen agronomic efficiency (NAE), was calculated using the equation:

NAE (kg grain per $k g$ of $N)=\frac{Y G \text { Fert }- \text { YG Unfert }}{\text { QNAC }}$

in which: YG Fert is the grain yield of the treatments with $\mathrm{N}$ fertilization $\left(\mathrm{kg} \mathrm{ha}^{-1}\right)$; $\mathrm{YG}$ Unfert is the grain yield of the treatment without $\mathrm{N}$ fertilization $\left(\mathrm{kg} \mathrm{ha}^{-1}\right)$; and QNAc is the $\mathrm{N}$ topdressing rate $\left(\mathrm{kg} \mathrm{ha}^{-1}\right)$.

The efficiency of recovery of applied N (NRE), was calculated using the equation:

$\operatorname{RE}(\%)=\frac{(\mathrm{N} \text { Exported Fert }-\mathrm{N} \text { Exported Unfert })}{\text { QNAC }} \times 100$

in which $\mathrm{N}$ Exported Fert is the amount of $\mathrm{N}$ exported in grains of the fertilized plots $\left(\mathrm{kg} \mathrm{ha}^{-1}\right) ; \mathrm{N}$ Exported Unfert is the amount of $\mathrm{N}$ exported in grains of the unfertilized plots $\left(\mathrm{kg} \mathrm{ha}^{-1}\right)$; and QNAc is the $\mathrm{N}$ topdressing rate $\left(\mathrm{kg} \mathrm{ha}^{-1}\right)$.

The partial N balance (PN balance), was calculated using the equation:

PN balance $(\mathrm{kg} \mathrm{N} \mathrm{ha-1})=(Q N A C+Q N A s)-N$ Exported Eq. 4

in which: QNAc is the $\mathrm{N}$ topdressing rate $\left(\mathrm{kg} \mathrm{ha}^{-1}\right)$; QNAs is the $\mathrm{N}$ rate at sowing $\left(30 \mathrm{~kg} \mathrm{ha}^{-1}\right)$; and $\mathrm{N}$ Exported is the amount of $\mathrm{N}$ exported in grains $\left(\mathrm{kg} \mathrm{ha}^{-1}\right)$.

The quadratic model had the best fit to describe the crop yield response to $\mathrm{N}$ rates. The maximum corn yield of the response curve was considered the agronomic optimum $\mathrm{N}$ rate (AONR). The AONR ( $\mathrm{kg} \mathrm{ha}^{-1}$ of $\mathrm{N}$ ) was calculated as: 
$\operatorname{AONR}\left(\mathrm{kg} \mathrm{ha}^{-1}\right.$ of $\left.\mathrm{N}\right)=\frac{b}{2 a}$

Eq. 5

in which: $b$ is the linear coefficient and $a$ is the quadratic coefficient from the quadratic equation.

\section{Experimental design and treatments}

The experimental design was a complete randomized block, in both trials. Treatments were arranged in split-split plots, with three repetitions in Lages and four in Atalanta. Two hybrids were tested in the main plots: AG9025 PRO3 (super early cycle, relative maturity: 130) and P30F53 VYH (early cycle, relative maturity: 135), hereafter referred to as AG9025 and P30F53, respectively. Two sowing periods were evaluated in the split plots: early and late spring. Sowings were carried out on October 15, 2015 (early) and December 5, 2015 (late) in Lages and September 20, 2016 (early) and December 5, 2016 (late) in Atalanta. Four $\mathrm{N}$ top-dress rates were evaluated in split-split plots equivalent to $0,150,300$ and $450 \mathrm{~kg} \mathrm{ha}^{-1}$ of $\mathrm{N}$. These rates are equivalent to $0,0.5,1.0$ and 1.5, the amount of $\mathrm{N}$ recommended by CQFS RS/SC (2004) for an expected yield of $21 \mathrm{Mg} \mathrm{ha}^{-1}$. Each experimental unit was composed of four rows, six meter long. Around each plot, there was one additional corn row, at the four ends, separating the experimental units. This extra border row did not receive $\mathrm{N}$ top-dress fertilization.

\section{Statistical analyses}

Data were tested for normality (Shapiro-Wilk's test) and homoscedasticity of variances (Bartlett's test). After verification of these assumptions, ANOVA was performed by the $\mathrm{F}$ test $(p \leq 0.05)$ for each location separately, considering a split-split plots model. When $F$ values were significant, means were compared by Tukey's test $(p \leq 0.05)$ for the sowing dates and hybrids. A polynomial regression analysis $(p \leq 0.05)$ was used for $N$ rates. Pearson correlation coefficients were submitted to the Student t-test $(p \leq 0.05)$. These analyses were performed using R software (R Development Core Team, 2017).

\section{RESULTS}

\section{Contextualization of meteorological data}

Both locations presented, in general, an adequate water supply. In five days, the highest accumulated water deficit was -3 and $-7 \mathrm{~mm}$ in Lages and Atalanta, respectively (Figure 1). The experimental site in Atalanta has a lower altitude $(586 \mathrm{~m})$ than in Lages $(849 \mathrm{~m})$. This altitude difference allows sowing corn some days earlier in Atalanta without having the risk of frosts, as it had higher average soil (data not shown) and air temperatures (Figure 1). The choice of the sowing day in early spring during the preferential sowing time at both places was to optimize the crop efficiency to use temperature and solar radiation.

In Lages, the photoperiod on the sowing day was $12: 41$ and $13: 41 \mathrm{~h}$ for the early and late spring sowings, respectively. In Atalanta, the photoperiods on the sowing day were 11:59 and 13:39 $\mathrm{h}$ for the sowings performed during early and late spring, respectively (Figure 1). The summer solstice occurred on December 22, 2015 and December 21, 2016 with photoperiods of 13:46 and 13:44 h, respectively. The photoperiod on the day of harvest in Lages was 11:53, 10:57, 11:42, and 10:57 for AG9025 sown in early spring, AG9025 sown in late spring, P30F53 sown in early spring and P30F53 sown in late spring, respectively. The photoperiods on the harvest day in Atalanta were 12:18, 11:04, 12:18 and 10:55 h for AG9025 sown in early spring, AG9025 sown in late spring, P30F53 sown in early spring and P30F53 sown in late spring, respectively.

In Lages, corn reached the beginning of flowering on January 2, February 1, January 6 and February 10 for AG9025 sown in early spring, AG9025 sown in late spring, P30F53 
sown in early spring and P30F53 sown in late spring, respectively. In the Atalanta, corn flowering started on December 12, February 5, December 18 and February 8 for AG9025 sown in early spring, AG9025 sown in late spring, P30F53 sown in early spring and P30F53 sown in late spring, respectively.

\section{Grain yield}

Grain yield ranged from 5.8 to $17.4 \mathrm{Mg} \mathrm{ha}^{-1}$ in Lages and from 6.1 to $20.8 \mathrm{Mg} \mathrm{ha}^{-1}$ in Atalanta. The maximum yields recorded in the two locations demonstrate the high yield potential of corn first crops in the subtropical region of Brazil. In both locations, grain yield was influenced by the interactions between hybrids and sowing dates, hybrids and $\mathrm{N}$ rates and sowing dates and $\mathrm{N}$ rates.

In the early spring sowing, the grain yield of AG9025 was 10 and $17.2 \%$ higher than the productivity of P30F53 in Lages and Atalanta, respectively, on the average of $\mathrm{N}$ rates (Figures 2e and 2f). In the late spring sowing, the P30F53 hybrid showed greater yield stability, presenting similar yields on the two sowing dates in Lages and a slight reduction of $11.4 \%$ when sowing was delayed from September to December in Atalanta. The hybrid AG9025 showed low adaptability to late spring sowing, presenting yield reductions of 53.95 and $28.7 \%$ in Lages and Atalanta, respectively, compared to early spring.

In both locations, the two hybrids presented a quadratic response to the increase in the $\mathrm{N}$ rate (Figure 2). For P30F53, the agronomic optimum $\mathrm{N}$ rates (AONRs) were 351 and $370 \mathrm{~kg} \mathrm{ha}^{-1}$ in the Lages and Atalanta, respectively. The AONR of AG9025 was obtained with rates of 290 and $340 \mathrm{~kg} \mathrm{ha}^{-1}$ of $\mathrm{N}$ in the Lages and Atalanta, respectively. In Lages, the yield of P30F53 showed a greater response to the increase in the $\mathrm{N}$ rate on the average of the sowing dates (Figure 2a). In Atalanta, AG9025 had a higher grain yield than P30F53 up to the rate of $450 \mathrm{~kg} \mathrm{ha}^{-1}$ of $\mathrm{N}$, and the hybrids showed a similar average yield (Figure $2 \mathrm{~b}$ ).

Nitrogen-rates effect on yield was quadratic (Figures $2 c$ and $2 d$ ). However, the magnitude of the response to the increase in $\mathrm{N}$ rates was greater in the early spring sowing than in the late spring sowing. The AONR of corn e sown in early spring was 345 and $375 \mathrm{~kg} \mathrm{ha}^{-1}$ of $\mathrm{N}$ in Lages and Atalanta, respectively. On the other hand, the AONR of corn sown in late spring was 270 and $331 \mathrm{~kg} \mathrm{ha}^{-1}$ of top-dressed N in Lages and Atalanta, respectively. Averaging the results of both locations and hybrids, in early spring sowing, the maximum grain yield was $39 \%$ greater and it was achieved using $20 \%$ higher $\mathrm{N}$ top-dress rate than late spring.

\section{Yield components}

The number of ears per plant was affected by the $\mathrm{N}$ rates and sowing date in Atalanta and by the interaction between the hybrids and sowing date and the $\mathrm{N}$ rates and sowing date in Lages. In Lages, AG9025 had a lower ear index than P30F53 in the late spring sowing (Table 2). Both hybrids showed a reduction in the ear index when sown in late spring in Atalanta. Increasing the $\mathrm{N}$ rates increased the ear index linearly when corn was sown in early spring. The number of ears per plant did not respond to the $\mathrm{N}$ application rate when corn was sown in late spring in Lages (Figure 3e). In Atalanta, regardless of the hybrid or sowing time, the increase in the $\mathrm{N}$ rate improved the ear index (Figure $3 \mathrm{f}$ ).

The percentage of barren plants was affected by the interactions between the hybrids and sowing date and $\mathrm{N}$ rates and sowing date in Lages. The percentage of plants without ears was affected by the hybrid type, sowing date and $\mathrm{N}$ application rate in Atalanta. In Lages, AG9025 showed a higher percentage of barren plants than P30F53 when sown in late spring (Table 2). As the $\mathrm{N}$ application rate increased, the number of plants without ears sown in early spring decreased. On the other hand, there was no effect of the $\mathrm{N}$ rate on the percentage of barren plants when the crop was sown in late spring (Figure 4e). 
(a)

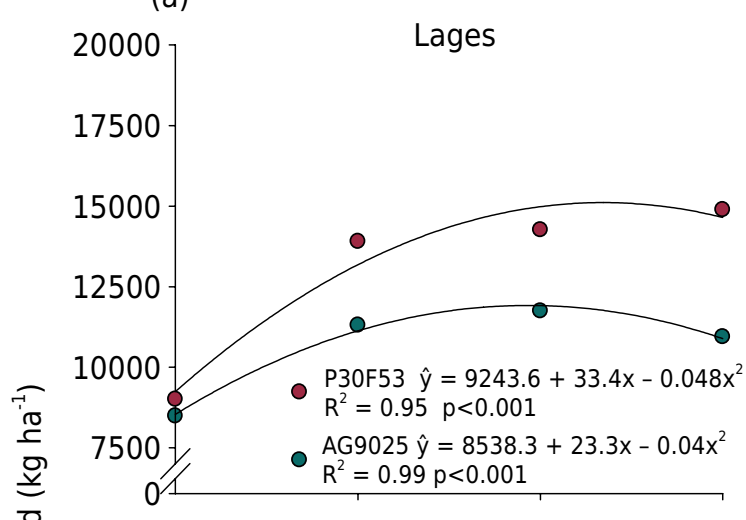

(c)

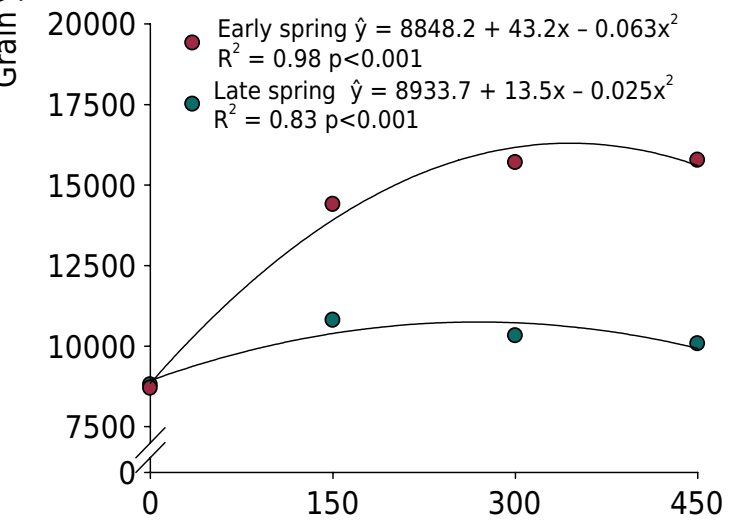

(b)

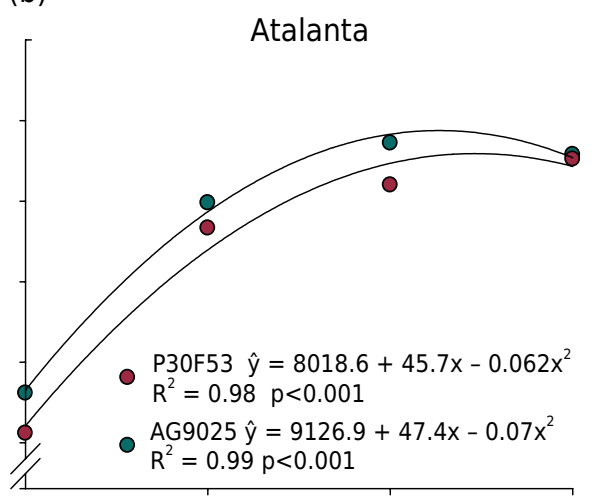

(d)
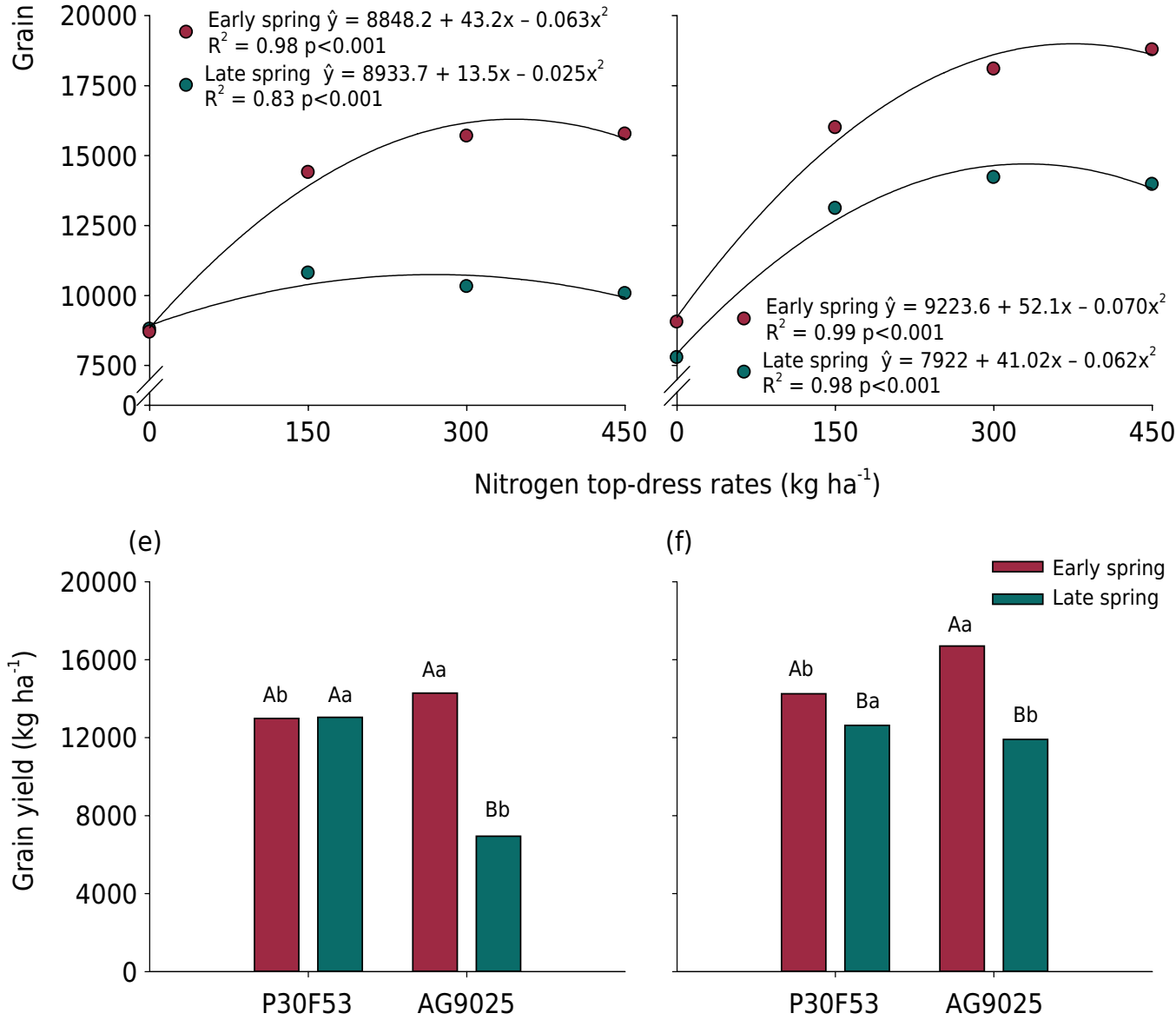

(f)

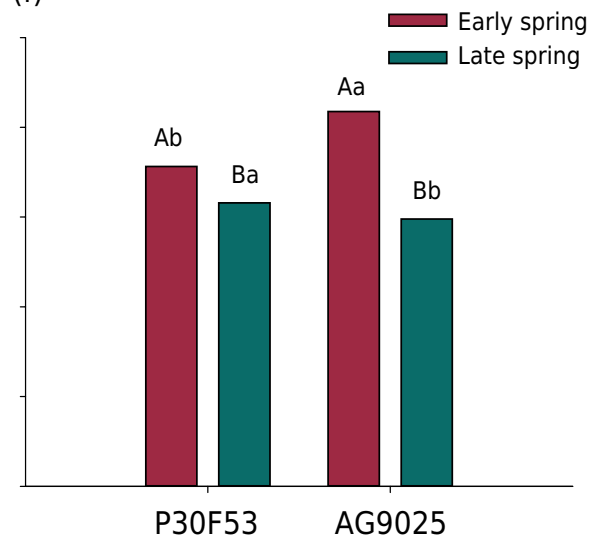

Figure 2. Corn grain yield according to the rates of topdressed $\mathrm{N}$ and the hybrid type ( $\mathrm{a}$ and $\mathrm{b}$ ), rates of topdressed $\mathrm{N}$ and sowing time (c and $\mathrm{d}$ ) and hybrid type and sowing time (e and f) in Lages ( $a, c$ and e) and Atalanta (b, $d$ and f). Uppercase letters distinguish between the meantime of sowing dates and lowercase letters for hybrids by Tukey's test $(p<0.05)$.

In Atalanta, AG9025 presented a higher percentage of plants without ears than P30F53, regardless of the sowing date and $\mathrm{N}$ rate. In the late spring sowing, the number of plants without ears increased by $164 \%$ compared to those sown in early spring on average for the hybrids and $\mathrm{N}$ application rates (Table 2 ). Higher $\mathrm{N}$ rates reduced the number of plants without ears, regardless of the hybrid type or sowing time (Figure 4f).

The number of kernels per ear was the variable that affected grain yield the most in the present study. This yield component was affected by the interactions between the hybrids and $\mathrm{N}$ rates and sowing date and $\mathrm{N}$ rates in both locations. However, the interaction between the hybrids and sowing date was only significant in Lages. 
Table 2. Ear per plant, percentage of barren plants, kernels per ear and thousand grain weight according to the sowing time and corn hybrid

\begin{tabular}{|c|c|c|c|c|c|c|}
\hline \multirow{2}{*}{ Sowing periods } & \multicolumn{3}{|c|}{ Lages } & \multicolumn{3}{|c|}{ Atalanta } \\
\hline & P30F53 & AG9025 & Average & P30F53 & AG9025 & Average \\
\hline & \multicolumn{6}{|c|}{ Ear per plants (No.) } \\
\hline Early spring & $0.94 \mathrm{Aa}$ & $1.00 \mathrm{Aa}$ & 0.97 & 0.98 & 0.99 & $0.98 \mathrm{~A}$ \\
\hline Late spring & $0.94 \mathrm{Aa}$ & $0.77 \mathrm{Bb}$ & 0.85 & 0.95 & 0.91 & $0.93 \mathrm{~B}$ \\
\hline \multirow[t]{2}{*}{ Average } & 0.94 & 0.88 & & 0.97 & 0.95 & \\
\hline & \multicolumn{6}{|c|}{ Plants without ear (\%) } \\
\hline Early spring & $5.89 \mathrm{Aa}$ & $2.95 \mathrm{Ba}$ & 4.42 & 2.82 & 3.03 & $2.93 \mathrm{~B}$ \\
\hline Late spring & $6.17 \mathrm{Ab}$ & $22.73 \mathrm{Aa}$ & 14.45 & 6.23 & 9.24 & $7.73 \mathrm{~A}$ \\
\hline \multirow[t]{2}{*}{ Average } & 6.03 & 12.84 & & $4.53 b$ & $6.14 \mathrm{a}$ & \\
\hline & \multicolumn{6}{|c|}{ Kernels per ear (No.) } \\
\hline Early spring & $543 \mathrm{Aa}$ & $494 \mathrm{Aa}$ & 518 & 509 & 473 & $491 \mathrm{~A}$ \\
\hline Late spring & $581 \mathrm{Aa}$ & $287 \mathrm{Bb}$ & 434 & 468 & 418 & $443 \mathrm{~B}$ \\
\hline \multirow[t]{2}{*}{ Average } & 562 & 390 & & 488 & 445 & \\
\hline & \multicolumn{6}{|c|}{ Thousand grain weight $(\mathrm{g})$} \\
\hline Early spring & $390 \mathrm{Ab}$ & $440 \mathrm{Ba}$ & 415 & $363 \mathrm{Ab}$ & $450 \mathrm{Aa}$ & 407 \\
\hline Late spring & $380 \mathrm{Ab}$ & $477 \mathrm{Aa}$ & 428 & $375 \mathrm{Ab}$ & $422 \mathrm{Ba}$ & 398 \\
\hline Average & 385 & 459 & & 369 & 436 & \\
\hline
\end{tabular}

* Uppercase letters distinguish between averages in the column and lowercase letters in the row.

In Lages, AG9025 had a lower number of kernels than P30F53 in the late spring sowing (Table 2). The two hybrids showed a quadratic increase in this variable as the $\mathrm{N}$ application rate increased (Figures $4 \mathrm{a}$ and $4 \mathrm{~b}$ ). The P30F53 hybrid showed a higher number of kernels than AG9025 at all N rates, except for the control (without N) in Atalanta, which had similar values between the two hybrids. The number of kernels per ear had a lower response to the increase in the $\mathrm{N}$ rate in the late spring sowing (Figures $3 \mathrm{a}$ and $3 \mathrm{~b}$ ).

In both locations, the thousand-kernel weight was affected by the interactions between the hybrids and sowing date and the $\mathrm{N}$ rates and sowing date. In Atalanta, the interaction between the $\mathrm{N}$ application rates and hybrids was also significant. AG9025 produced heavier kernels than P30F53 (Table 2). AG9025 also had the highest kernel weight in late sowing in Lages and the lowest in Atalanta. The kernel weight increased with the increasing $\mathrm{N}$ application rate (Figures $3 \mathrm{c}$ and $3 \mathrm{~d}$ ). In Atalanta, there was a linear increase in kernel weight for P30F53 and a quadratic increase for AG9025 with an increasing N application rate (Figure $4 \mathrm{~d}$ ).

\section{Nitrogen in grains and nitrogen exports}

Nitrogen content in grains (NCG) was affected by the $\mathrm{N}$ application rate in Lages and by the interaction between the $\mathrm{N}$ application rate and sowing time in Atalanta. The NCG increased linearly in Lages with the enhancement of the $\mathrm{N}$ rate, regardless of hybrid or sowing date (Figure $5 \mathrm{a}$ ). In Atalanta, the $\mathrm{N}$ content of kernels increased linearly when corn was sown in early spring (Figure $5 b$ ). There was a quadratic increase in NCG in the late spring sowing, stabilizing their values at rates above $150 \mathrm{~kg} \mathrm{ha}^{-1}$ of $\mathrm{N}$.

The amount of $\mathrm{N}$ exported by grains ( $\mathrm{N}$ Exported) was affected by the interaction between the hybrids and sowing date in Lages and the interaction between the $\mathrm{N}$ rate and sowing date in both locations. AG9025 showed $46 \%$ less N exported than P30F53 when sown in late spring in Lages (Figure $5 e$ ). Greater $\mathrm{N}$ export was observed as the rates of $\mathrm{N}$ increased in both sowing periods (Figures $5 \mathrm{c}$ and $5 \mathrm{~d}$ ), with $\mathrm{N}$ export of $112 \mathrm{~kg} \mathrm{ha}^{-1}$ when no $\mathrm{N}$ was applied and $231 \mathrm{~kg} \mathrm{ha}^{-1}$ when rate of $450 \mathrm{~kg} \mathrm{ha}^{-1}$ was applied, on the 
(a)

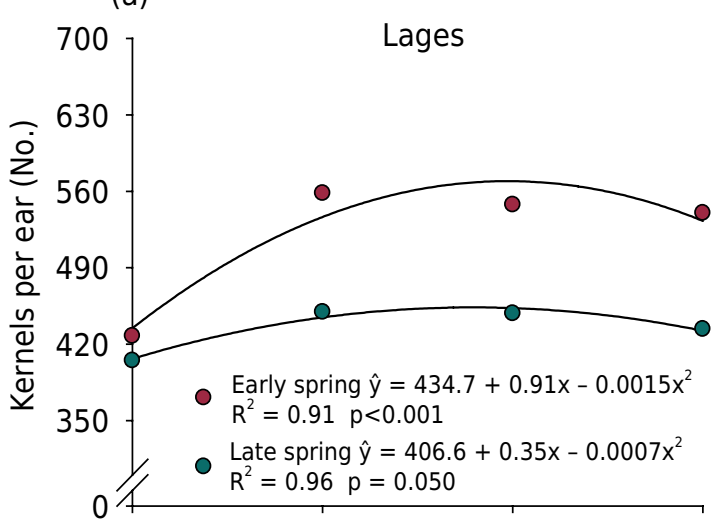

(c)

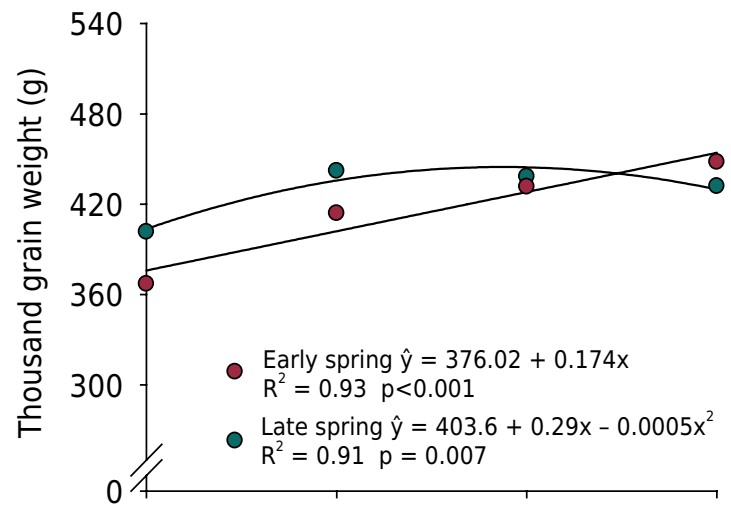

(e)

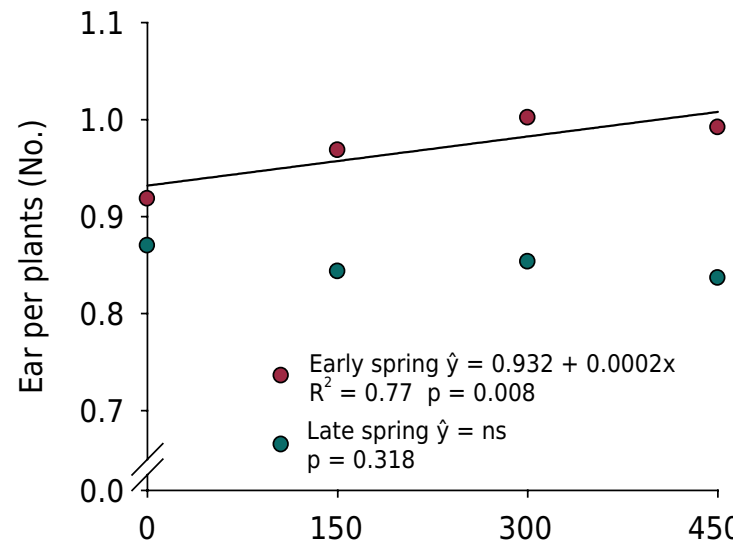

(b)

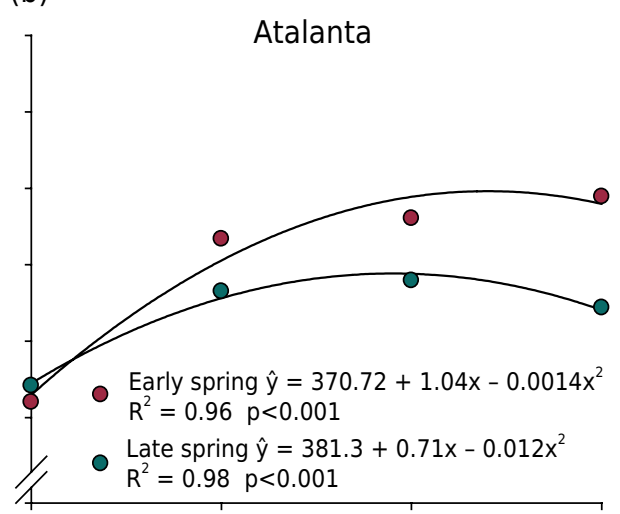

(d)

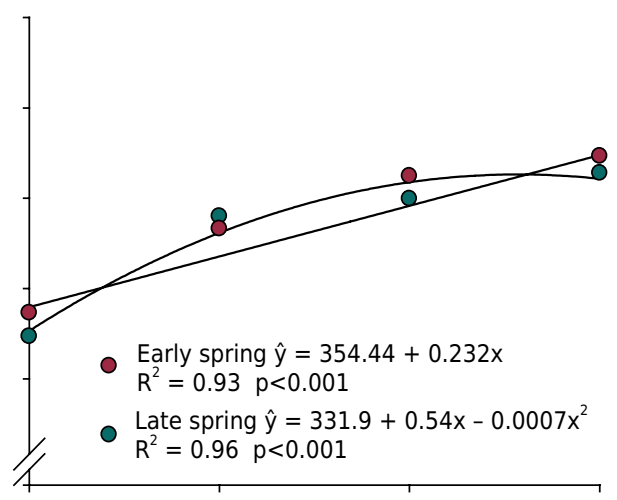

(f)

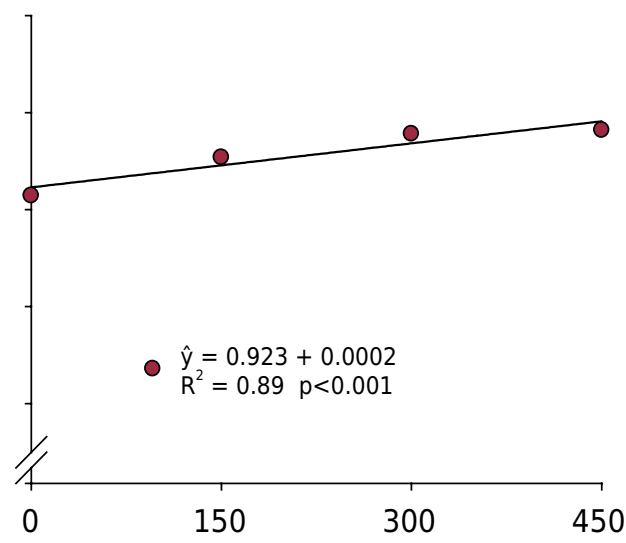

Nitrogen top-dress rates $\left(\mathrm{kg} \mathrm{ha}^{-1}\right)$

Figure 3. Number of kernels per ear ( $a$ and $b$ ) and thousand kernel weight ( $c$ and $d$ ) and number of ears per plant (e) according to $\mathrm{N}$ topdressing rates and sowing time. Number of ears per plant according to $\mathrm{N}$ topdressing rates ( $\mathrm{f}$ ) in Lages ( $\mathrm{a}, \mathrm{c}$ and $\mathrm{e}$ ) and Atalanta (b, $\mathrm{d}$ and $\mathrm{f}$ ).

average of sowing dates and locations. At rates higher than $300 \mathrm{~kg} \mathrm{ha}^{-1}$ of $\mathrm{N}$, corn had higher $\mathrm{N}$ export when sown in early spring. This trend was also observed when no $\mathrm{N}$ was top-dressed in Atalanta.

\section{Nitrogen use efficiency}

In Lages, $\mathrm{N}$ agronomic efficiency (NAE) was affected by the interactions between the $\mathrm{N}$ rate and hybrids and the $\mathrm{N}$ rate and sowing date. In Atalanta, the main effects of the sowing date and $\mathrm{N}$ application rate affected NAE. The increase of the $\mathrm{N}$ rate decreased NAE. There was a reduction of $0.08 \mathrm{~kg}$ grain per $\mathrm{kg}$ of $\mathrm{N}$ for each $\mathrm{kg} \mathrm{ha}^{-1}$ of $\mathrm{N}$ applied increase, on the average of both experimental sites. Corn sown in late spring showed 
(a)

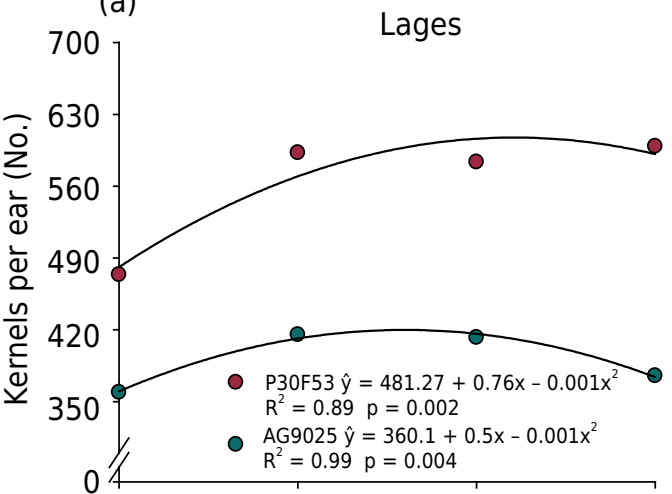

(c)

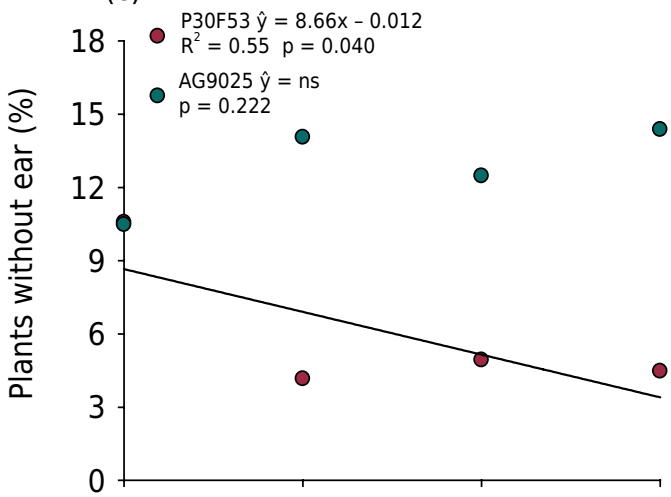

(e)

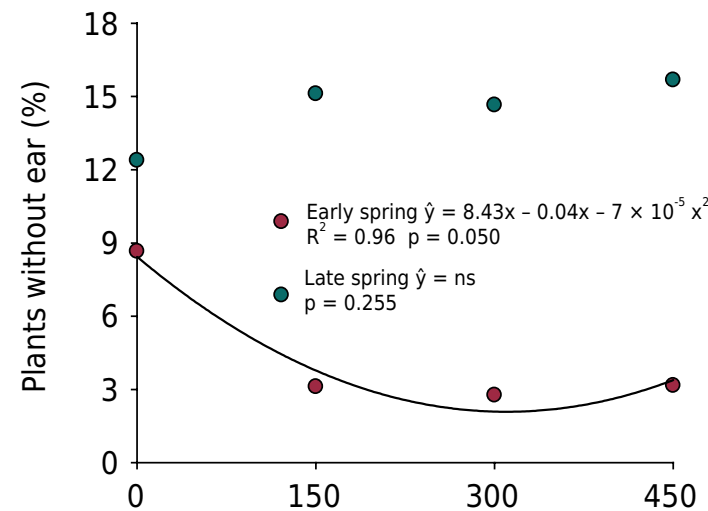

(b)

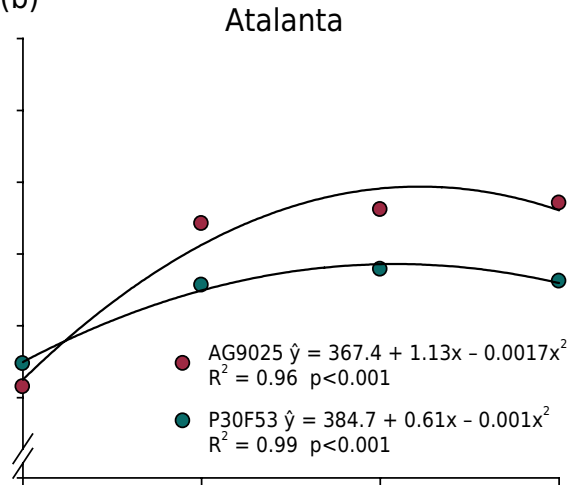

(d)

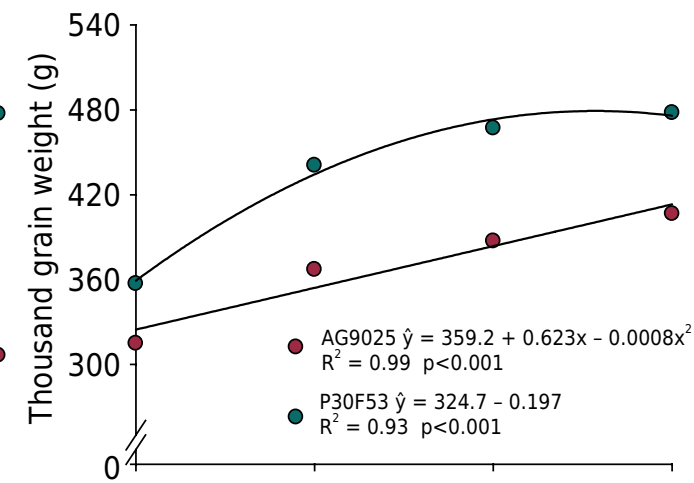

(f)

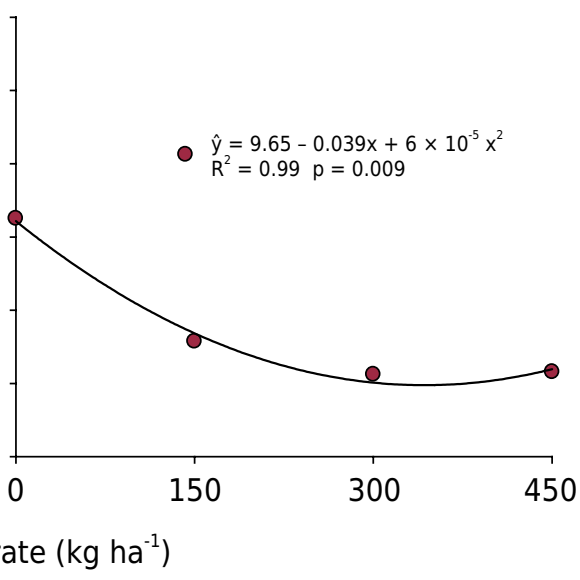

Figure 4. Kernels per ear ( $a$ and b), percentage of plants without ears (c) and thousand kernel weight (d), according to the rates of topdressed $\mathrm{N}$ and corn hybrids. Percentage of plants without ears according to the rates of topdressed $\mathrm{N}$ and sowing time (e) and nitrogen topdress rates $(\mathrm{f})$ in Lages ( $a, c$ and e) and Atalanta (b, $d$ and $f)$.

a $47 \%$ lower NAE than that sown in early spring, regardless of the $\mathrm{N}$ application rate. AG9025 presented a $44 \%$ lower NAE than P30F53 in Lages (Table 3).

Efficiency of recovery of applied $\mathrm{N}$ (NRE) was affected by the $\mathrm{N}$ rates and sowing dates in Lages. In Atalanta, NRE was influenced by the interaction between these two factors. There was a linear reduction in NRE as the rate of $\mathrm{N}$ was increased in both locations (Table 3), with a reduction of 0.09 for each $\mathrm{kg} \mathrm{ha}^{-1}$ of $\mathrm{N}$ applied, average of the locations. At all rates, with the exception of the $150 \mathrm{~kg} \mathrm{ha}^{-1}$ rate in Atalanta, corn sown in late spring showed a lower NRE than that sown in early spring. P30F53 and AG9025 presented similar NRE values.

Partial $\mathrm{N}$ balance (PN balance) was affected by the interactions between the hybrids and sowing date, $\mathrm{N}$ rates and hybrids and $\mathrm{N}$ rates and sowing date in both locations. The $\mathrm{N}$ 
(a)

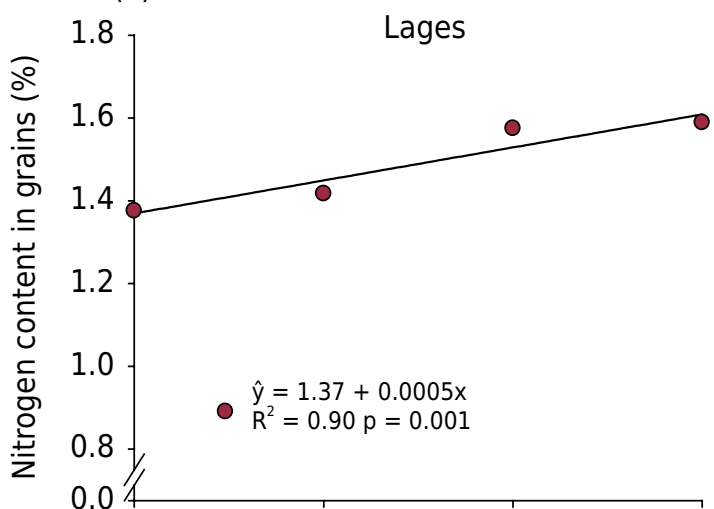

(c)

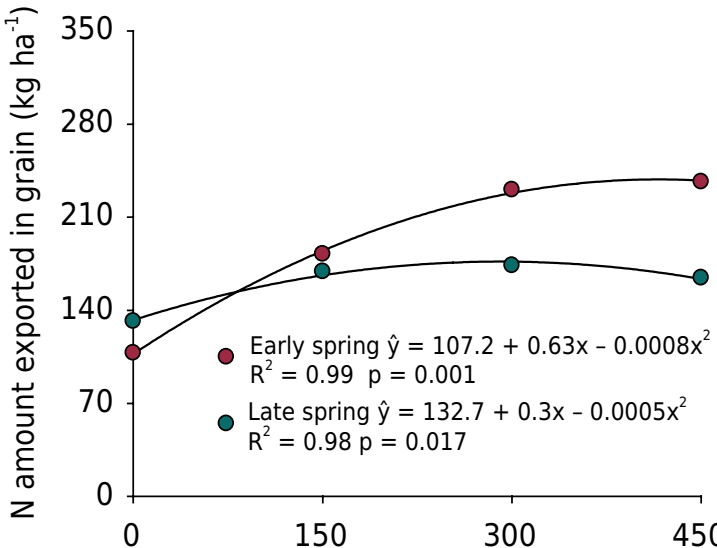

(b)

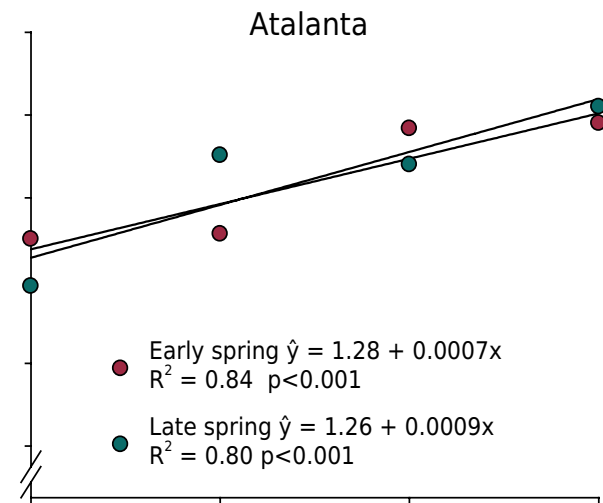

(d)

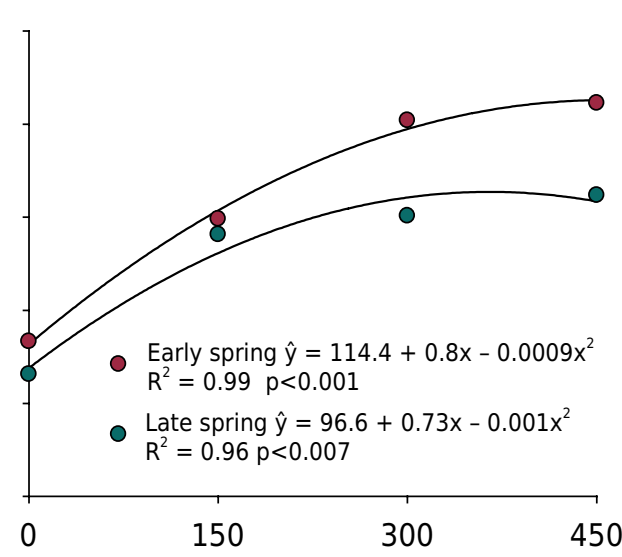

(e)

Nitrogen top-dress rates $\left(\mathrm{kg} \mathrm{ha}^{-1}\right)$

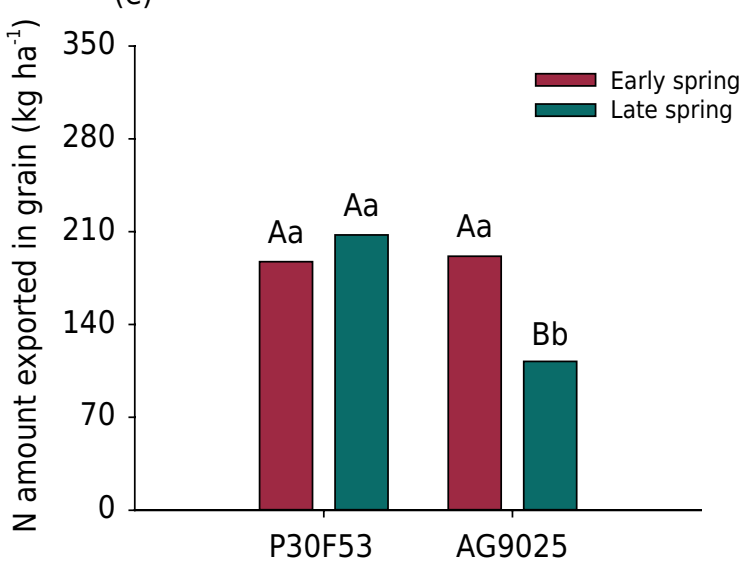

Figure 5. Nitrogen content in grains according to the $\mathrm{N}$ topdressing rates (a) and $\mathrm{N}$ topdressing rates and corn sowing time (b). Amount of nitrogen exported in grains according to the $\mathrm{N}$ topdressing rates and corn sowing time ( $c$ and d) and corn sowing time and corn hybrids (e) in Lages (a, c and e) and Atalanta ( $b$ and $d)$. Uppercase letters distinguish between the mean time of sowing dates and lowercase letters for hybrids by Tukey's test $(p<0.05)$.

rate increase promoted an enhancement of the PN balance in both locations, regardless of the sowing date or hybrid type (Figures $6 a, 6 b, 6 c$ and $6 d$ ).

Disregarding $\mathrm{N}$ losses, the PN balance was neutral at rates of 181 and $176 \mathrm{~kg} \mathrm{ha}^{-1}$ of $\mathrm{N}$ for P30F53 and 136 and $178 \mathrm{~kg}$ of N ha ${ }^{-1}$ for AG9025 in the Lages and Atalanta, respectively. In the early spring sowing, the PN balance was neutral at rates of 163 and $206 \mathrm{~kg} \mathrm{ha}^{-1}$ of $\mathrm{N}$ in Lages and Atalanta, respectively. Corn sown in late spring had a neutral PN balance at a rate of $153 \mathrm{~kg} \mathrm{ha}^{-1}$ of $\mathrm{N}$. In both locations, AG9025 showed a higher PN balance than P30F53 when sown in late spring. (Table 2). This trend was accentuated with the increase in the $\mathrm{N}$ topdress rate. 
Table 3. Nitrogen agronomic efficiency, efficiency of recovery of applied nitrogen and partial nitrogen balance according to the nitrogen topdress rate, sowing time and corn hybrid

\begin{tabular}{|c|c|c|c|c|c|c|}
\hline Treatment & \multicolumn{3}{|c|}{ Lages } & \multicolumn{3}{|c|}{ Atalanta } \\
\hline \multicolumn{7}{|c|}{ Nitrogen agronomic efficiency (NAE) } \\
\hline N Rates (kg ha $\left.{ }^{-1}\right)$ & P30F53 & AG9025 & Average & P30F53 & AG9025 & Average \\
\hline 150 & $32.7 \mathrm{Aa}$ & $18.8 \mathrm{Ab}$ & 25.7 & 42.4 & 39.4 & $40.9 \mathrm{~A}$ \\
\hline 300 & $17.5 \mathrm{Ba}$ & $10.9 \mathrm{Bb}$ & 14.2 & 25.7 & 25.9 & $25.8 \mathrm{~B}$ \\
\hline 450 & $13.1 \mathrm{Ca}$ & $5.5 \mathrm{Cb}$ & 9.3 & 18.9 & 16.5 & $17.7 \mathrm{C}$ \\
\hline Average & 21.1 & 11.7 & & 29.0 & 27.3 & \\
\hline $\mathrm{Eq}$ & $52.6-0.078 x$ & $50.2-0.076 x$ & & - & - & $51.4-0.078 x$ \\
\hline$R^{2}$ & $0.94 *$ & $0.99 *$ & & - & - & $0.97^{*}$ \\
\hline N Rates (kg ha $\left.{ }^{-1}\right)$ & Early spring & Late spring & Average & Early spring & Late spring & Average \\
\hline 150 & $38.1 \mathrm{Aa}$ & $13.4 \mathrm{Ab}$ & 25.7 & 46.3 & 35.6 & $40.9 \mathrm{~A}$ \\
\hline 300 & $23.3 \mathrm{Ba}$ & $5.1 \mathrm{Bb}$ & 14.2 & 30.1 & 21.5 & $25.8 \mathrm{~B}$ \\
\hline 450 & $15.7 \mathrm{Ca}$ & $2.8 \mathrm{Bb}$ & 9.3 & 21.6 & 13.8 & $17.7 \mathrm{C}$ \\
\hline Average & 25.7 & 7.1 & & $32.7 \mathrm{a}$ & $23.6 \mathrm{~b}$ & \\
\hline Eq & $57.3-0.082 x$ & $45.4-0.073 x$ & & - & - & $51.4-0.078 x$ \\
\hline $\mathrm{R}^{2}$ & $0.97 *$ & $0.97 *$ & & - & - & $0.97 *$ \\
\hline \multicolumn{7}{|c|}{ Efficiency of recovery of applied N (NRE) } \\
\hline N Rates (kg ha ${ }^{-1}$ ) & Early spring & Late spring & Average & Early spring & Late spring & Average \\
\hline 150 & 49.6 & 24.9 & $37.3 \mathrm{~A}$ & $61.4 \mathrm{Aa}$ & $70.0 \mathrm{Aa}$ & 65.7 \\
\hline 300 & 40.9 & 14.0 & $27.5 \mathrm{AB}$ & $55.4 \mathrm{Aa}$ & $39.7 \mathrm{Bb}$ & 47.6 \\
\hline 450 & 28.6 & 7.3 & $18.0 \mathrm{~B}$ & $39.9 \mathrm{Ba}$ & $29.9 \mathrm{Bb}$ & 34.1 \\
\hline Average & 39.7 a & $15.4 \mathrm{~b}$ & & 52.2 & 46.5 & \\
\hline Eq & - & - & $46.8-0.064 x$ & $73.8-0.072 x$ & $86.6-0.134 x$ & - \\
\hline $\mathrm{R}^{2}$ & - & - & $0.99 *$ & $0.94 *$ & $0.92 *$ & - \\
\hline \multicolumn{7}{|c|}{ Parcial nitrogen balance (PN balance) } \\
\hline Sowing periods & P30F53 & AG9025 & Average & P30F53 & AG9025 & Average \\
\hline Early spring & $67.7 \mathrm{Aa}$ & $63.5 \mathrm{Bb}$ & 65.6 & $33.5 \mathrm{Aa}$ & $24.5 \mathrm{Ba}$ & 29.0 \\
\hline Late spring & $47.6 \mathrm{Ab}$ & $142.8 \mathrm{Aa}$ & 95.2 & $65.4 \mathrm{Aa}$ & $81.4 \mathrm{Aa}$ & 73.4 \\
\hline Average & 57.6 & 103.1 & & 49.5 & 52.9 & \\
\hline
\end{tabular}

Uppercase letters distinguish between averages in the column and lowercase letters in the row; * Equation with $p \leq 0.05$.

\section{DISCUSSION}

\section{Grain yield and yield components}

Yield response to $\mathrm{N}$ rate was greater when corn was sown in early spring than in late spring. High levels of organic matter, associated with high soil temperature and humidity, increase soil $\mathrm{N}$ availability (Srivastava et al., 2017). The presence of long fallow periods before sowing has the same effect (Kramberger et al., 2009). Thus, it is likely that when corn was sown in December, the availability of $\mathrm{N}$ from organic matter in the soil was greater than when sowing was performed in early spring. The combination of soil with 2.3-3.6 \% organic matter and the extension of a hot and humid fallow period of 81-106 days (Figure 1) possibly increased the amount of $\mathrm{N}$ available in the soil for the crop sown in late spring (Caviglia et al., 2014; Maltese et al., 2019). Therefore, the lower yield response to the increase in $\mathrm{N}$ rates in late spring sowing can be partially attributed to the greater amount of $\mathrm{N}$ availability in the soil.

In temperate and subtropical regions, plants sown in late spring are subjected to lower temperatures, photoperiods and radiation during grain filling (Bonelli et al., 2016; 
(a)

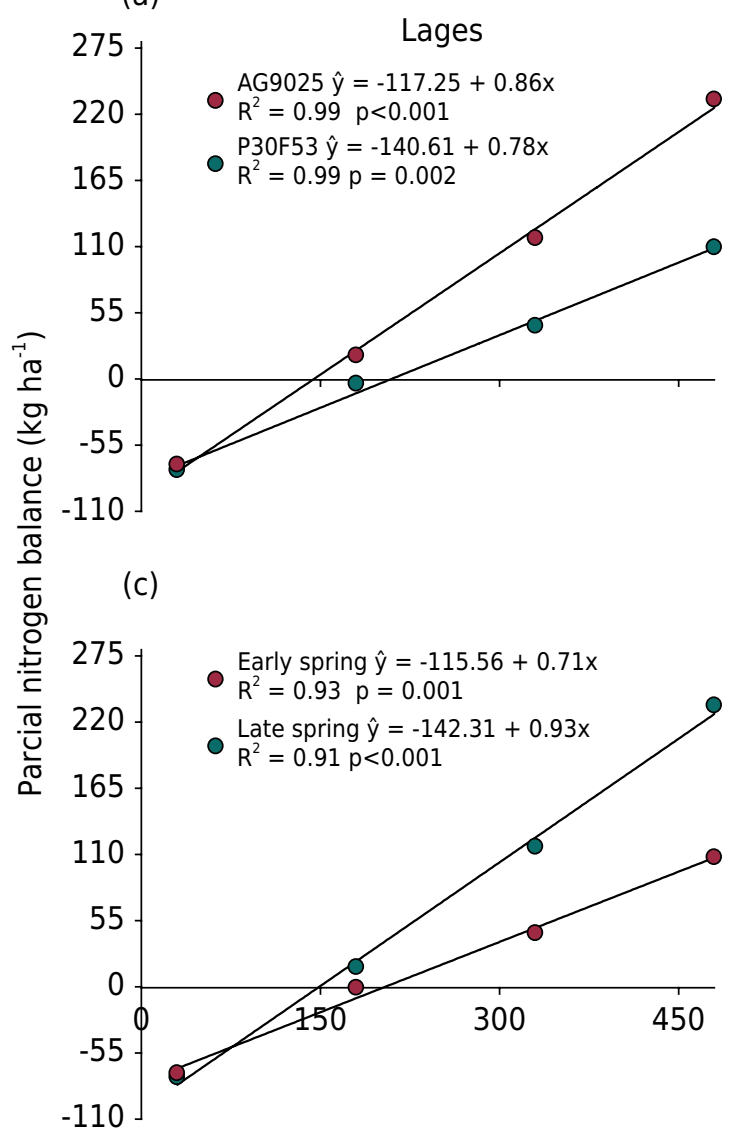

(b)

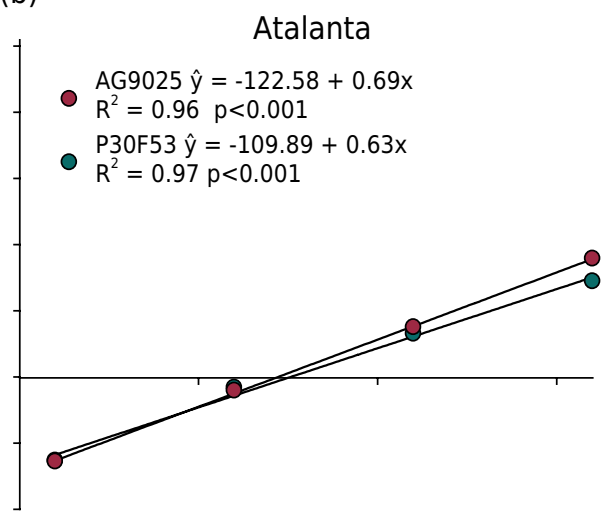

(d)

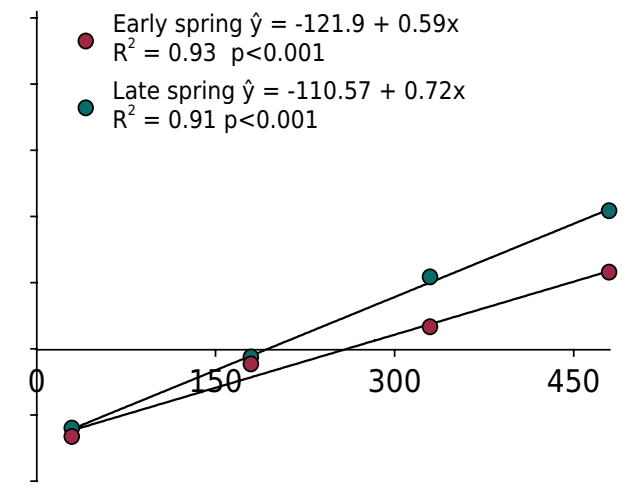

Nitrogen rates $\left(\mathrm{kg} \mathrm{ha}^{-1}\right)$

Figure 6. Partial nitrogen balance according to the $\mathrm{N}$ topdressing rates and corn hybrids ( $\mathrm{a}$ and $\mathrm{b}$ ) and $\mathrm{N}$ topdressing rates and corn sowing time ( $\mathrm{c}$ and $\mathrm{d}$ ) in Lages ( $\mathrm{a}$ and $\mathrm{c}$ ) and Atalanta ( $\mathrm{b}$ and $\mathrm{d}$ ).

Maltese et al., 2019). In late spring sowing, the lower temperature during grain filling decreases the radiation use efficiency (Andrade et al., 1993, 2000). Thus, corn sown in late spring had a lower yield potential (Figures $2 \mathrm{e}$ and $2 \mathrm{f}$ ) than that sown in early spring due to these environmental conditions. The same yield response to the sowing date was reported by Tsimba et al. (2013), Caviglia et al. (2014) and Bonelli et al. (2016). The lower yield response to the increase in the $\mathrm{N}$ topdressing rate (Figure 2 ) suggests reducing the $\mathrm{N}$ dose when corn is sown in late spring. This procedure is important to avoid excess mineral $\mathrm{N}$ in the soil, which can increase nutrient losses by volatilization and leaching (Pan et al., 2016; Cantarella et al., 2018).

Corn sown in late spring was impacted by the enhancement of necrotrophic diseases, which increased stalk and ear rot during grain filling. This effect was more pronounced for AG9025 in Lages, which may help to explain the greater reduction in grain yield of this hybrid compared to that in Atalanta. Necrotrophic diseases are biotic stresses that limit corn yield in late spring sowing in the south of Brazil. This tendency is aggravated by high $\mathrm{N}$ rates or $\mathrm{N}$ deficiency (Wordell Filho and Spagnollo, 2013; Berghetti et al., 2020).

Greater kernel weight of AG9025 than P30F53 contributed to the higher yield of this hybrid in the early spring sowing than that of P30F53. However, the P30F53 hybrid showed higher yield stability in the late spring sowing. P30F53 presented small changes in the number of ears per plant, number of kernels per ear and percentage of barren plants. Conversely, the super early hybrid AG9025 demonstrated high sensitivity to the stresses associated with late spring sowing, expressing greater variations in the yield components with the delay of sowing date. In Lages, the AG9025 produced heavier kernels in the late sowing 
date. However, the increase in kernel weight did not compensate for the reduction in the other components. Studies conducted in regions at latitudes higher than $35^{\circ} \mathrm{N}$ or $\mathrm{S}$ reported large reductions in kernel weight and small effects on the number of kernels when sowing was delayed (Tsimba et al., 2013; Baum et al., 2019; Jiang et al., 2020), expressing an inverse relationship of these yield components compared to that observed in the present study. This pattern can be attributed to the more abrupt reduction in the photoperiod, radiation, and temperature in regions with a temperate climate than in subtropical regions. Baum et al. (2019) concluded that the lower the latitude, the smaller the impact of hybrid relative maturity on grain yield according to the sowing time.

In Lages, the low response to $\mathrm{N}$ rates of AG9025 in the late spring sowing increased the yield difference between the two hybrids when they were sown in December (Figure 2a). On the other hand, in Atalanta, the lower magnitude of sowing stresses in late spring allowed AG9025 to mitigate the reduction in kernel number per ear and the increase in the number of barren plants by enhancing its kernel weight with the increasing $\mathrm{N}$ application rate. As a result, the grain yield of both hybrids did not differ when they were sown in late spring.

At high latitudes, radiation and temperature decrease abruptly during grain filling on late sowing dates. These fast climatic changes result in grain yield decreases as the hybrid maturity class increases (Capristo et al., 2007; Bonelli et al., 2016; Jiang et al., 2020). However, as latitude is reduced, this effect is mitigated (Baum et al., 2019). In a subtropical environment, where the decrease in temperature and radiation after the summer solstice is milder and the growing season is longer, early cycle hybrids may present greater yield stability than super early cycle hybrids on late sowing dates. The faster development speed of super early hybrids, such as AG9025, makes them more demanding in terms of soil and favorable atmospheric conditions. They usually present lower yield stability because they are less tolerant to biotic and abiotic stresses (Sangoi et al., 2001; Panison et al., 2019).

Increase in grain yield as a function of the $\mathrm{N}$ application rate is explained by the increases in the numbers of kernels per ear and ears per plant and kernel weight, as well as the reduction in the number of plants without ears. The effect of increasing the $\mathrm{N}$ rate on corn yield was higher in the early spring sowing than in the late spring sowing, which was mainly due to the greater effect of $\mathrm{N}$ fertilizer on the number of kernels per ear and the number of ears per plant at sowings performed in early spring. Regardless of the sowing time or hybrid used, the number of kernels per ear showed a high correlation with yield ( $r=0.81 *$ and $0.82 *$ for Lages and Atalanta) and was the yield component most associated with grain yield, a pattern also observed by Mastrodomenico et al. (2018).

The lower yield response to the increase in $\mathrm{N}$ rates recorded in the late spring sowing is due to the smaller impact that $\mathrm{N}$ had on the numbers of kernels per ear, ears per plant and barren plants at this sowing time. The highest daily thermal sum from emergence to flowering at late sowing dates accelerates corn development (Caviglia et al., 2014; Srivastava et al., 2018; Lizaso et al., 2018), favoring vegetative growth in comparison to reproductive growth, which reduces the number of grains per ear and kernel weight (Cirilo and Andrade, 1994; Lizaso et al., 2018).

Lower atmospheric temperature and the reduced availability of solar radiation during grain filling have been shown to reduce the kernel weight when corn is sown at the end of spring, as observed by Cirilo and Andrade (1994), Cerrudo et al. (2013) and Bonelli et al. (2016). However, in this study, the smaller numbers of ears and kernels per plant prevented the decrease in kernel weight. Therefore, the late spring sowing limited yield mainly because it reduced the kernel number per ear but not the kernel weight. This behavior is probably associated with the lower latitude where the present study was carried out compared to the studies conducted by Cirilo and Andrade (1994), Cerrudo et al. (2013) and Bonelli et al. (2016). 


\section{Nitrogen use efficiency}

Increase in $\mathrm{N}$ rate promoted a linear increase in the grain $\mathrm{N}$ content, which led to an improvement in the grain protein concentration, as there is $5.68 \mathrm{~kg}$ of crude protein in corn grains for each $\mathrm{kg}$ of $\mathrm{N}$ (Sriperm et al., 2011). Higher $\mathrm{N}$ topdressing rates increased the grain yield and grain protein content, increasing the protein yield. Mastrodomenico et al. (2018) found that the application of $252 \mathrm{~kg} \mathrm{ha}^{-1}$ of $\mathrm{N}$ increased protein production in corn by $60 \%$ compared to unfertilized corn. Although the $\mathrm{N}$ content in grains increased as the rate of $\mathrm{N}$ increased, the export of this nutrient was more associated with grain yield ( $r=0.90 *$ and $0.94 *$ for Lages and Atalanta).

The NAE decreased with the sowing delay from early to late spring, decreasing linearly with the increase in the rate of $\mathrm{N}$. Several studies have shown that NAE decreases with the increase in the $\mathrm{N}$ rate (Moll et al., 1982; Srivastava et al., 2018; Duan et al., 2019). The data obtained in the present study also emphasize that the greater the yield potential of corn, the higher the NAE.

Greater environmental restrictions resulting from the delay of the sowing date from September/October to December and the increase in the N rate reduced the NAE. This effect was more accentuated for AG9025, the hybrid with a smaller group of relative maturity. The combination of super early hybrids, late sowing and high $\mathrm{N}$ rates can even generate negative NAEs, as observed in the Lages. Therefore, the technical indications should consider the interaction among these three factors to reduce the $\mathrm{N}$ topdressing rate when corn is grown in late spring sowings.

The efficiency of recovery of applied $\mathrm{N}$ demonstrates how much of the applied $\mathrm{N}$ was allocated to the grains. It also decreased linearly with the increase in the $\mathrm{N}$ rate. A similar pattern was reported by Mueller et al. (2017). The NRE was lower in the late spring sowing due to the smaller grain yield than in the early spring sowing. Therefore, NRE behaved similarly to NAE regarding the effect of the evaluated treatments.

Variations in the partial $\mathrm{N}$ balance (PN Balance) showed that the input or output of $\mathrm{N}$ in the system was dependent on the hybrid and sowing date. The high PN Balance of the super early hybrid when sown in late spring is explained by the low yield of the hybrid. When corn is sown in early spring, there is a greater demand for $\mathrm{N}$ fertilization to make the PN Balance neutral, which should be considered in the indications of the $\mathrm{N}$ rate. The high yield values in the absence of $\mathrm{N}$ top-dress fertilization (8.5 and $7.8 \mathrm{Mg} \mathrm{ha}^{-1}$ in Lages and Atalanta, respectively; Figure 2 ) is indicative of the high availability of $\mathrm{N}$ in soil. However, the negative PN Balance reduces the level of organic matter over time and the levels of total and mineral $\mathrm{N}$ in the soil (Ladha et al., 2011; Duan et al., 2019). This can cause the degradation of soil quality (Palm et al., 2014; Lorenz et al., 2019) and limit the yield potential in later crops (Oldfield et al., 2019). On the other hand, excess $\mathrm{N}$ can cause environmental damage, such as increased levels $\mathrm{N}_{2} \mathrm{O}$ emissions (Gu et al., 2013; Keeler et al., 2016; Gourevitch et al., 2018). Thus, adjusting the N rates in first-crop corn in southern Brazil, according to the sowing date and corn relative maturity group, is also relevant to minimizing environmental impacts and maintaining soil quality over time.

\section{Agronomic prospect}

Lower response of grain yield to the increase in $\mathrm{N}$ fertilization suggests the use of more conservative $\mathrm{N}$ rates when corn is sown at the end of spring in the south of Brazil. Corn growers can use at least $20 \%$ lower $\mathrm{N}$ rates when the sowing date of corn is delayed to late spring to maximize grain yield. A reduction of $47 \%$ in the $\mathrm{N}$ rate is feasible in late spring sowings, considering the efficient use of $\mathrm{N}$ fertilizers. This is important to avoid the loss of excess mineral $\mathrm{N}$ in soil and prevent an increase in production costs. The $\mathrm{N}$ balance should be determined after each growing season, considering the export of $14.7 \mathrm{~kg} \mathrm{Mg}^{-1}$ of N in the grain produced. Farmers must be aware that the suppression of $\mathrm{N}$ fertilization may lead 
to a negative $\mathrm{N}$ balance. Under this situation, $\mathrm{N}$ needs to be restored to the soil system to avoid the loss of organic matter and the grain yield potential depreciation. The use of super early hybrids with high yield potential increases the demand for $\mathrm{N}$, especially when sowing is performed in early spring. Therefore, the technical indications for $\mathrm{N}$ fertilization in the first corn crop should be revised in the subtropical environments of southern Brazil. They should consider the sowing date and the hybrid relative maturation group as determining factors. Additionally, further economic studies need to be carried out.

\section{CONCLUSIONS}

When corn is sown in early spring, maximum grain yield is achieved using $20 \%$ higher $\mathrm{N}$ top-dress rate than in late spring, with a $39 \%$ higher grain yield than the maximum yield reached in late spring in the subtropical region of Brazil.

Nitrogen agronomic efficiency use is on average $47 \%$ lower in late spring sowing than in early spring sowing. Regardless of hybrid or sowing date, it decreases as the applied $\mathrm{N}$ rate increases. In early spring sowing, the hybrid AG9025 had $17 \%$ higher grain yield than P30F53. Conversely, the early cycle hybrid P30F53 showed greater yield stability in late spring sowing than the super early cycle hybrid AG9025, presenting a $36 \%$ higher grain yield than the hybrid super early cycle.

\section{SUPPLEMENTARY DATA}

Supplementary data to this article can be found online at https://www.rbcsjournal.org/ wp-content/uploads/articles_xml/1806-9657-rbcs-46-e0210087/1806-9657-rbcs-46e0210087-suppl01.pdf.

\section{ACKNOWLEDGMENTS}

To the Brazilian National Research Council (CNPq), Coordination for the Improvement of Higher Education Personnel (CAPES) and to FAPESC/PAP/UDESC for the financial support to the experiment execution. Postgraduate scholarship of Coordination for the Improvement of Higher Education Personnel (CAPES) of the Brazilian Ministry of Education. We thank the National Council for Scientific and Technological Development (CNPq) for the research grants. We also thank the reviewers of this manuscript for their very constructive comments.

\section{AUTHOR CONTRIBUTIONS}

Conceptualization: (D) Antonio Eduardo Coelho (equal) and (D) Luis Sangoi (equal).

Funding acquisition: (D) Alvadi Antonio Balbinot Junior (equal) and (D) Luis Sangoi (equal). Investigation: (D) Antonio Eduardo Coelho (equal) and (iD Marcos Cardoso Martins Júnior (equal).

Methodology: (D) Antonio Eduardo Coelho (equal) and (D) Luis Sangoi (equal).

Project administration: (D) Antonio Eduardo Coelho (equal) and (D) Luis Sangoi (equal).

Software: (D) Hugo François Kuneski (equal) and (D) Marcos Cardoso Martins Júnior (equal).

Supervision: (D) Luis Sangoi (lead).

Validation: (D) Alvadi Antonio Balbinot Junior (equal) and (D) Hugo François Kuneski (equal).

Visualization: (D) Antonio Eduardo Coelho (lead). 
Writing - original draft: (D) Antonio Eduardo Coelho (lead).

Writing - review \& editing: (D) Antonio Eduardo Coelho (lead), (D) Alvadi Antonio Balbinot Junior (equal) and (D) Luis Sangoi (equal).

\section{REFERENCES}

Alvares CA, Stape JL, Sentelhas PC, Gonçalves JLM, Sparovek G. Köppen's climate classification map for Brazil. Meteorol Z. 2013;22:711-28. https://doi.org/10.1127/0941-2948/2013/0507

Andrade $\mathrm{FH}$, Otegui $\mathrm{ME}$, Vega $\mathrm{C}$. Intercepted radiation at flowering and kernel number in maize. Agron J. 2000;92:92-7. https://doi.org/10.2134/agronj2000.92192x

Andrade $\mathrm{FH}$, Uhart SA, Cirilo A. Temperature affects radiation use efficiency in maize. Field Crop Res. 1993;32:17-25. https://doi.org/10.1016/0378-4290(93)90018-I

Austin R, Osmond D, Shelton S. Optimum nitrogen rates for maize and wheat in North Carolina. Agron J. 2019;111:2558-68. https://doi.org/10.2134/agronj2019.04.0286

Baligar VC, Duncan RR, Fageria NK. Soil-plant interaction on nutrient efficiency in plants: An overview. In: Baligar VC, Duncan RR, editors. Crops as enhancers of nutrient use. San Diego: Academic; 1990. p. 351-73.

Baum ME, Archontoulis SV, Licht MA. Planting date, hybrid maturity, and weather effects on maize yield and crop stage. Agron J. 2019;111:303-13. https://doi.org/10.2134/agronj2018.04.0297

Berghetti J, Sheidt BT, Casa RT, Coelho AE, Sangoi L, Gonçalves MJ, Leolato LS. Nitrogen rates and sowing dates influence on white spot disease severity and grain yield of maize. Rev Bras Milho Sorgo. 2020;19:e1191. https://doi.org/10.18512/rbms2020v19e1191

Bonelli LE, Monzon JP, Cerrudo A, Rizzalli RH, Andrade FH. Maize grain yield components and source-sink relationship as affected by the delay in sowing date. Field Crop Res. 2016;198:215-25. https://doi.org/10.1016/j.fcr.2016.09.003

Cantarella H, Otto R, Soares JR, Silva AGB. Agronomic efficiency of NBPT as a urease inhibitor: A review. J Adv Res. 2018;13:19-27. https://doi.org/10.1016/j.jare.2018.05.008

Capristo PR, Rizzalli RH, Andrade FH. Ecophysiological yield components of maize hybrids with contrasting maturity. Agron J. 2007;99:1111-8. https://doi.org/10.2134/agronj2006.0360

Cattelan AJ, Dall'Agnol A. The rapid soybean growth in Brazil. Oilseeds \& fats Crops and Lipids. 2018;25:D102. https://doi.org/10.1051/ocl/2017058

Caviglia OP, Melchiori RJM, Sadras VO. Nitrogen utilization efficiency in maize as affected by hybrid and $\mathrm{N}$ rate in late-sown crops. Field Crop Res. 2014;168:27-37. https://doi.org/10.1016/j.fcr.2014.08.005

Cerrudo A, Di Matteo J, Fernandez E, Robles M, Pico LO, Andrade FH. Yield components of maize as affected by short shading periods and thinning. Crop Pasture Sci. 2013;64:580-7. https://doi.org/10.1071/CP13201

Cirilo AG, Andrade FH. Sowing date and maize productivity: I. Crop growth and dry matter partitioning. Crop Sci. 1994;34:1039-43. https://doi.org/10.2135/cropsci1994.0011183X003400040037x

Coelho AE, Sangoi L, Balbinot Junior AA, Fioreze SL, Berghetti J, Kuneski HF, Leolato LS, Martins Júnior MC. Growth patterns and yield of maize (Zea mays) hybrids as affected by nitrogen rate and sowing date in southern Brazil. Crop Pasture Sci. 2020;71:976-86. https://doi.org/10.1071/CP20077

Coelho AE, Sangoi L, Casa RT, Kuneski HF, Panison F, Leolato LS, Durli MM, Berghetti J. Sanidade de híbridos de milho em função da época de semeadura, doses de $\mathrm{N}$ em áreas com e sem rotação de culturas. Colloq Agrariae. 2019;15:101-13. https://doi.org/10.5747/ca.2019.v15.n2.a289

Comissão de Química e Fertilidade do Solo - CQFS-RS/SC. Manual de calagem e adubação para os Estados do Rio Grande do Sul e de Santa Catarina. 11. ed. Porto Alegre: Sociedade Brasileira de Ciência do Solo - Núcleo Regional Sul; 2016. 
Comissão de Química e Fertilidade do Solo - CQFS-RS/SC. Manual de calagem e adubação para os Estados do Rio Grande do Sul e de Santa Catarina. 10. ed. Porto Alegre: Sociedade Brasileira de Ciência do Solo - Núcleo Regional Sul; 2004.

Companhia Nacional de Abastecimento - Conab - Série Histórica da Área Plantada, produtividade e Produção: Milho - primeira safra. Brasília, DF: Conab; 2020. [cited 2020 May 11]. Available from: https://www.conab.gov.br/info-agro/safras/serie-historica-das-safras

DeBruin JL, Schussler JR, Mo H, Cooper M. Grain yield and nitrogen accumulation in maize hybrids released during 1934 to 2013 in the US Midwest. Crop Sci. 2017;57:1431-46. https://doi.org/10.2135/cropsci2016.08.0704

Duan J, Shao Y, He L, Li X, Hou G, Li S, Feng W, Zhu Y, Wang Y, Xie Y. Optimizing nitrogen management to achieve high yield, high nitrogen efficiency and low nitrogen emission in winter wheat. Sci Total Environ. 2019;697:134088. https://doi.org/10.1016/j.scitotenv.2019.134088

Gourevitch JD, Keeler BL, Ricketts TH. Determining socially optimal rates of nitrogen fertilizer application. Agric Ecosyst Environ. 2018;254:292-9. https://doi.org/10.1016/j.agee.2017.12.002

Gu B, Ge Y, Chang SX, Luo W, Chang J. Nitrate in groundwater of China: Sources and driving forces. Glob Environ Change. 2013;23:1112-21. https://doi.org/10.1016/j.gloenvcha.2013.05.004

Haegele JW, Below FE. Transgenic corn rootworm protection increases grain yield and nitrogen use of maize. Crop Sci. 2013;53:585-94. https://doi.org/10.2135/cropsci2012.06.0348

Jiang W, Thapa S, Jessup K, Hao B, Hou X, Marek T, Becker J, Bell J, Xue Q. Corn response to later than traditional planting dates in the Texas High Plains. Crop Sci. 2020;60:1004-20. https://doi.org/10.1002/csc2.20042

Keeler BL, Gourevitch JD, Polasky S, Isbell F, Tessum CW, Hill JD, Marshall JD. The social costs of nitrogen. Sci Adv. 2016;2:e1600219. https://doi.org/10.1126/sciadv.1600219

Kolling DF, Sangoi L, Leolato LS, Panison F, Coelho AE, Kuneski HF. Can an increase in nitrogen rate mitigate damages caused by uneven spatial distribution of maize plants at the sowing row? Acta Sci Agron. 2019;41:e39874. https://doi.org/10.4025/actasciagron.v41i1.39874

Kramberger B, Gselman A, Janzekovic M, Kaligaric M, Bracko B. Effects of cover crops on soil mineral nitrogen and on the yield and nitrogen content of maize. Eur J Agron. 2009;31:103-9. https://doi.org/10.1016/j.eja.2009.05.006

Ladha JK, Reddy CK, Padre AT, Van Kessel C. Role of nitrogen fertilization in sustaining organic matter in cultivated soils. J Environ Qual. 2011;40:1756-66. https://doi.org/10.2134/jeq2011.0064

Lizaso JI, Ruiz-Ramos M, Rodríguez L, Gabaldon-Leal C, Oliveira JA, Lorite IJ, Sánchez D,

García E, Rodríguez A. Impact of high temperatures in maize: Phenology and yield components. Field Crop Res. 2018;216:129-40. https://doi.org/10.1016/j.fcr.2017.11.013

Lorenz K, Lal R, Ehlers K. Soil organic carbon stock as an indicator for monitoring land and soil degradation in relation to United Nations' Sustainable Development Goals. Land Degrad Dev. 2019;30:824-38. https://doi.org/10.1002/ldr.3270

Maltese NE, Melchiori RJM, Maddonni GA, Ferreyra JM, Caviglia OP. Nitrogen economy of early and late-sown maize crops. Field Crop Res. 2019;231:40-50. https://doi.org/10.1016/j.fcr.2018.11.007

Mastrodomenico AT, Haegele JW, Seebauer JR, Below FE. Yield stability differs in commercial maize hybrids in response to changes in plant density, nitrogen fertility, and environment. Crop Sci. 2018;58:230-41. https://doi.org/10.2135/cropsci2017.06.0340

Moll RH, Kamprath EJ, Jackson WA. Analysis and interpretation of factors which contribute to efficiency of nitrogen utilization. Agron J. 1982;74:562-4. https://doi.org/10.2134/agronj1982.00021962007400030037x

Mueller SM, Camberato J, Messina C, Shanahan J, Zhang H, Vyn TJ. Late-split nitrogen applications increased maize plant nitrogen recovery but not yield under moderate to high nitrogen rates. Agron J. 2017;109:2689-99. https://doi.org/10.2134/agronj2017.05.0282 
Núcleo Estadual Paraná, Sociedade Brasileira de Ciência do Solo - NEPAR-SBCS. Manual de adubação e calagem para o estado do Paraná. 2nd ed. Curitiba: Núcleo Estadual Paraná, Sociedade Brasileira de Ciência do Solo; 2019.

Oldfield EE, Bradford MA, Wood SA. Global meta-analysis of the relationship between soil organic matter and crop yields. Soil. 2019;5:15-32. https://doi.org/10.5194/soil-5-15-2019

Palm C, Blanco-Canqui H, DeClerck F, Gatere L, Grace P. Conservation agriculture and ecosystem services: An overview. Agric Ecosyst Environ. 2014;187:87-105. https://doi.org/10.1016/j.agee.2013.10.010

Pan B, Lam SK, Mosier A, Luo Y, Chen D. Ammonia volatilization from synthetic fertilizers and its mitigation strategies: a global synthesis. Agric Ecosyst Environ. 2016;232:283-9. https://doi.org/10.1016/j.agee.2016.08.019

Panison F, Sangoi L, Durli MM, Leolato LS, Coelho AE, Kuneski HF, Liz VO. Timing and splitting of nitrogen sidedress fertilization of early corn hybrids for high grain yield. Rev Bras Cienc Solo. 2019;43:e0170338. https://doi.org/10.1590/18069657rbcs20170338

R Development Core Team. R: A language and environment for statistical computing. R Foundation for Statistical Computing. Vienna, Austria; 2016. Available from: http://www.R-project.org/

Ritchie SW, Hanway JJ, Benson GO. How a corn plant develops? Ames: lowa State University of Science and Technology; 1993.

Rocha KF, Souza M, Almeida DS, Chadwick DR, Jones DL, Mooney SJ, Rosolem CA. Cover crops affect the partial nitrogen balance in a maize-forage cropping system. Geoderma. 2020;360:114000. https://doi.org/10.1016/j.geoderma.2019.114000

Sangoi L, Almeida MLD, Lech VA, Gracietti LC, Rampazzo C. Desempenho de híbridos de milho com ciclos contrastantes em função da desfolha e da população de plantas. Sci Agric. 2001;58:271-6. https://doi.org/10.1590/S0103-90162001000200009

Sangoi L, Silva PD, Argenta G, Rambo L. Ecofisiologia da cultura do milho para altos rendimentos. Lages: Graphel; 2010.

Sangoi L, Silva PRF, Pagliarini NHF. Estratégias de manejo da adubação nitrogenada em milho na região sul do Brasil. Lages: Graphel; 2016.

Santos HG, Jacomine PKT, Anjos LHC, Oliveira VA, Oliveira JB, Coelho MR, Lumbreras JF, Cunha TJF. Sistema brasileiro de classificação de solos. 3. ed. rev. ampl. Rio de Janeiro: Embrapa Solos; 2013.

Sindelar AJ, Roozeboom KL, Gordon WB, Heer WF. Corn response to delayed planting in the central Great Plains. Agron J. 2010;102:530-6. https://doi.org/10.2134/agronj2009.0311

Soil Survey Staff. Keys to soil taxonomy. 12th ed. Washington, DC: United States Department of Agriculture, Natural Resources Conservation Service; 2014.

Sriperm N, Pesti GM, Tillman PB. Evaluation of the fixed nitrogen-to-protein (N:P) conversion factor (6.25) versus ingredient specific N:P conversion factors in feedstuffs. J Sci Food Agric. 2011;91:1182-6. https://doi.org/10.1002/jsfa.4292

Srivastava P, Singh R, Tripathi S, Singh P, Singh S, Singh H, Raghubanshi AS, Mishra PK. Soil carbon dynamics under changing climate-a research transition from absolute to relative roles of inorganic nitrogen pools and associated microbial processes: a review. Pedosphere. 2017;27:792-806. https://doi.org/10.1016/S1002-0160(17)60488-0

Srivastava RK, Panda RK, Chakraborty A, Halder D. Enhancing grain yield, biomass and nitrogen use efficiency of maize by varying sowing dates and nitrogen rate under rainfed and irrigated conditions. Field Crop Res. 2018;221:339-49. https://doi.org/10.1016/j.fcr.2017.06.019

Stevens WB, Hoeft RG, Mulvaney RL. Fate of nitrogen-15 in a long-term nitrogen rate study: II. Nitrogen uptake efficiency. Agron J. 2005;97:1046-53. https://doi.org/10.2134/agronj2003.0313

Thornthwaite CW, Mather JR. The water balance. Centerton NJ: Drexel Institute of Technology Laboratory of Climatology; 1955. 
Tsimba R, Edmeades GO, Millner JP, Kemp PD. The effect of planting date on maize grain yields and yield components. Field Crop Res. 2013;150:135-44. https://doi.org/10.1016/j.fcr.2013.05.028

Vargas VP, Sangoi L, Ernani PR, Picoli GJ, Cantarella H. Maize leaf phytotoxicity and grain yield are affected by nitrogen source and application method. Agron J. 2015;107:671-9. https://doi.org/10.2134/agronj14.0121

Wordell Filho JA, Spagnollo E. Cropping systens and nitrogen levels in the maize plant health and yield. Cienc Rural. 2013;43:199-205. https://doi.org/10.1590/S0103-84782013000200002 